\title{
Mitochondrially Targeted Effects of Berberine [Natural Yellow 18, 5,6-dihydro-9,10-dimethoxybenzo(g)-1,3-benzodioxolo(5,6-a) quinolizinium] on K1735-M2 Mouse Melanoma Cells: Comparison with Direct Effects on Isolated Mitochondrial Fractions
}

\author{
Gonçalo C. Pereira, Ana F. Branco, Júlio A. C. Matos, Sandro L. Pereira, Donna Parke, \\ Edward L. Perkins, Teresa L. Serafim, Vilma A. Sardão, Maria S. Santos, \\ Antonio J. M. Moreno, Jon Holy, and Paulo J. Oliveira \\ Center for Neurosciences and Cell Biology (G.C.P., A.F.B., J.A.C.M., S.L.P., T.L.S., V.A.S., M.S.S., P.J.O.) and Institute for \\ Marine Research (A.J.M.M.), Department of Zoology, University of Coimbra, Coimbra, Portugal; and Departments of \\ Biochemistry and Molecular Biology (D.P., E.L.P.) and Anatomy, Microbiology and Pathology (J.H.), University of Minnesota \\ Medical School, Duluth, Minnesota
}

Received July 10, 2007; accepted August 16, 2007

\begin{abstract}
Berberine [Natural Yellow 18, 5,6-dihydro-9,10-dimethoxybenzo(g)-1,3-benzodioxolo(5,6-a)quinolizinium] is an alkaloid present in plant extracts and has a history of use in traditional Chinese and Native American medicine. Because of its ability to arrest the cell cycle and cause apoptosis of several malignant cell lines, it has received attention as a potential anticancer therapeutic agent. Previous studies suggest that mitochondria may be an important target of berberine, but relatively little is known about the extent or molecular mechanisms of berberine-mitochondrial interactions. The objective of the present work was to investigate the interaction of berberine with mitochondria, both in situ and in isolated mitochondrial fractions. The data show that berberine is selectively accumulated by mitochondria, which is accompanied by arrest of cell proliferation, mitochondrial fragmentation and
\end{abstract}

depolarization, oxidative stress, and a decrease in ATP levels. Electron microscopy of berberine-treated cells shows a reduction in mitochondria-like structures, accompanied by a decrease in mitochondrial DNA copy number. Isolated mitochondrial fractions treated with berberine had slower mitochondrial respiration, especially when complex I substrates were used, and increased complex I-dependent oxidative stress. It is also demonstrated for the first time that berberine stimulates the mitochondrial permeability transition. Direct effects on ATPase activity were not detected. The present work demonstrates a number of previously unknown alterations of mitochondrial physiology induced by berberine, a potential chemotherapeutic agent, although it also suggests that high doses of berberine should not be used without a proper toxicology assessment.
Berberine (Fig. 1) is an isoquinoline alkaloid, usually extracted from rhizomes and roots from plants such as the Berbis, Coptis, and Hydrastis species. Such herbs have long been used in traditional Chinese and Native American medicine for the treatment of several maladies. Several pharmacologic properties have been attributed to berberine, including anti-inflammatory (Kuo et al., 2004), antimicrobial (Stermitz et al., 2000), antidiarrheal (Rabbani et al., 1987),

Article, publication date, and citation information can be found at http://jpet.aspetjournals.org.

doi:10.1124/jpet.107.128017 antiproliferative (Letasiova et al., 2006), antioxidative (Shirwaikar et al., 2006), and vasorelaxant (Ko et al., 2000) actions. Different types of effects such as up-regulation of cyclooxygenase-2 (Fukuda et al., 1999) and hypoxia-inducible factor-1 (Lin et al., 2004) expression, modulation of multidrug resistance protein expression (Lin et al., 1999), reduction of amyloid- $\beta$ peptide levels (Asai et al., 2007), formation of DNA adducts (Kuo et al., 1995), and cell cycle arrest (Lin et al., 2006; Mantena et al., 2006b) were also previously reported.

The antiproliferative properties of berberine raise the interesting possibility that the compound may be useful for anticancer therapeutics, and in fact, berberine has been

ABBREVIATIONS: berberine, Natural Yellow 18, 5,6-dihydro-9,10-dimethoxybenzo(g)-1,3-benzodioxolo(5,6-a)quinolizinium; MPT, mitochondrial permeability transition; CsA, cyclosporin A; DMSO, dimethyl sulfoxide; TMRM, tetramethyl rhodamine methyl ester; FCCP, carbonyl cyanide p-trifluoromethoxyphenylhydrazone; mtDNA, mitochondrial DNA; PCR, polymerase chain reaction; $\mathrm{CM}_{2} \mathrm{H}_{2} \mathrm{DCFDA}$, chloromethyl dichlorodihydrofluorescein diacetate acetyl ester; BSA, bovine serum albumin; TPP $^{+}$, tetraphenylphosphonium cation; EM, electron microscopy; RCR, respiratory control ratio; AM, acetoxy methyl ester. 


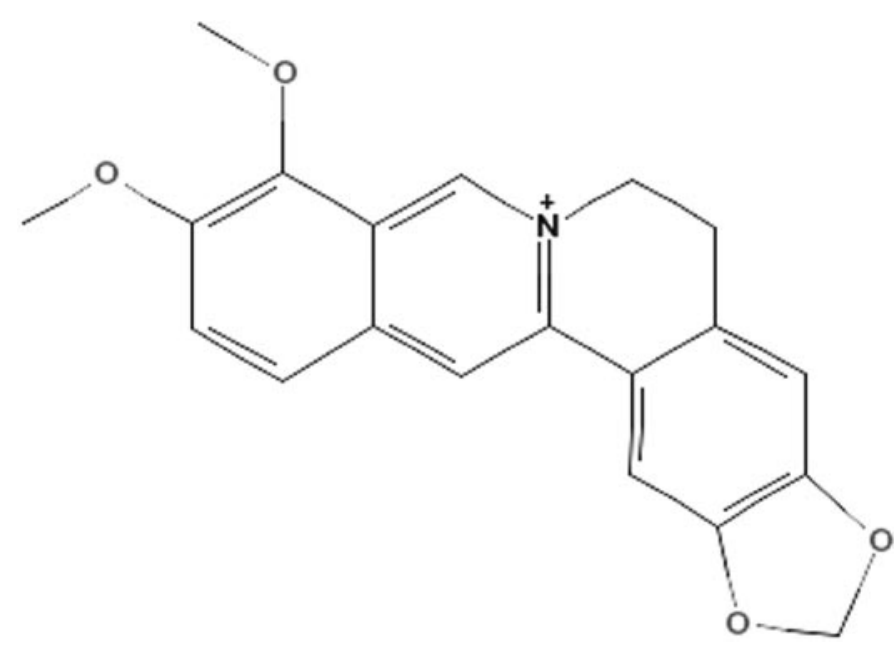

Fig. 1. Chemical structure of berberine.

shown to promote cell death in several transformed cell lines (Hwang et al., 2006; Lee et al., 2006; Letasiova et al., 2006; Lin et al., 2006; Mantena et al., 2006b). Apoptosis induced by berberine involves activation of caspases (Mantena et al., 2006b), increased Bax expression (Lin et al., 2006; Hwang et al., 2006; Lin et al., 2006; Mantena et al., 2006b), DNA fragmentation (Kuo et al., 1995; Hwang et al., 2006; Letasiova et al., 2006; Mantena et al., 2006b), and cytochrome $c$ release (Hwang et al., 2006; Lin et al., 2006), suggesting a possible role of mitochondria in the process (Mantena et al., 2006a; Jantova et al., 2007). Mitochondria could be involved via release of cytochrome $c$, which can occur through Bax interaction with mitochondrial membranes, as well as through the formation of the mitochondrial permeability transition (MPT) pore (Bouchier-Hayes et al., 2005). The MPT pore can be defined as a voltage-dependent, cyclosporin A (CsA)-sensitive, high-conductance channel of the inner mitochondrial membrane. Under the experimental conditions used in most in vitro studies, the MPT is accompanied by mitochondrial depolarization, respiratory inhibition or stimulation, matrix swelling, matrix pyridine nucleotide depletion, and release of intermembrane proteins, including cytochrome $c$ (Bernardi et al., 2006).

Apoptosis is an active process that requires cell energy for its execution. The cellular energy pool has an important role determining if cells die by apoptosis or necrosis (Kirveliene et al., 2003). In addition, the cell cycle also requires energy. Cyclin-dependent kinase-cyclin complexes ensure orderly passage through the cell cycle by the appropriate temporal phosphorylation of specific target proteins. When the cellular energy pool is lower, such target proteins are dephosphorylated, and cell cycle arrest occurs (Gemin et al., 2005). Mitochondrial generation of ATP can therefore be considered a significant control mechanism that helps govern both cell cycle progression and programmed cell death. Consequently, mitochondria hold a great promise as targets for therapeutic intervention.

For the present work, mouse melanoma K1735-M2 cells, a highly invasive melanoma cell line (Helige et al., 1993), were used to investigate berberine effects on cell proliferation and in situ mitochondrial physiology. In addition, isolated mitochondrial fractions were used to investigate direct berberine effects. We verified that berberine is accumulated by mito- chondria in K1735-M2 mouse melanoma cells, causing mitochondrial fragmentation, depolarization, and oxidative stress. Results obtained in isolated mitochondrial fractions confirmed induction of oxidative stress by berberine with complex I substrates. In addition, the present work describes an overall inhibition of mitochondrial respiration that appears more extensive when complex I substrates are used. It is demonstrated for the first time that berberine also enhances the calcium-induced MPT.

\section{Materials and Methods}

\section{Materials}

Berberine hemisulfate was obtained from Sigma-Aldrich (St. Louis, MO) and prepared in dimethyl sulfoxide (DMSO). The total volume of DMSO was always lower than $0.1 \%$, which had negligible effects in all experiments. Nevertheless, total volume was always lower than $0.1 \%$. Tetramethyl rhodamine methyl ester (TMRM), Hoechst 33342, and Calcein-AM were obtained from Molecular Probes (Carlsbad, CA). All other compounds were of the highest grade of purity commercially available.

\section{Animals}

Male Wistar rats ( 10 weeks old), housed at $22 \pm 2^{\circ} \mathrm{C}$ under artificial light for a 12-h light/day cycle and with access to water and food ad libitum, were used throughout the experiments. The research procedure was carried out in accordance with the European Requirement for Vertebrate Animal Research and with the internal Standards for Animal Research at the Center for Neurosciences and Cell Biology.

\section{Cell Culture}

K1735-M2 mouse melanoma cells (kindly offered by Dr. Lillian Repesh, Department of Anatomy, Microbiology, and Pathology, University of Minnesota School of Medicine, Duluth, MN) were cultured in Dulbecco's modified Eagle's medium (GIBCO, Grand Island, NY) with $10 \%$ Fetal Clone III (FC3; HyClone, Logan, UT) in an atmosphere of $5 \% \mathrm{CO}_{2}$ at $37^{\circ} \mathrm{C}$.

\section{Assessment of Cell Proliferation}

Sulforhodamine B assays were conducted to measure the effects of berberine on the proliferation of K1735-M2 cells, as described by Papazisis et al. (1997). Cells were seeded at a concentration of $1 \times$ $10^{5}$ cells $/ \mathrm{ml}$ in 24-well plates and allowed to recover for 1 day before drug addition. One of the wells was dried and washed once with phosphate-buffered saline to be used as a measure of cell mass at time 0 . Berberine at various concentrations $(0,10,25,50,75$, and 100 $\mu \mathrm{M})$ was incubated with K1735-M2 cells for 24, 48, 72, and $96 \mathrm{~h}$, times at which the plates were collected. After cell fixation and sulforhodamine labeling, absorbance was measured in a spectrophotometer at $540 \mathrm{~nm}$; the amount of dye released is proportional to the number of cells present in the dish and is a reliable indicator of cell proliferation.

\section{Confocal and Epifluorescence Imaging of K1735-M2 Cells}

Cells were seeded in glass-bottom dishes (P35G-1.5-14-C; Matek Corporation, Ashland, MA) at a concentration of 1 to $2 \times 10^{4}$ cell $/ \mathrm{ml}$. Cells were allowed to attach for $24 \mathrm{~h}$ and then treated with berberine or with solvent (DMSO) for the desired time.

Detection of Berberine Mitochondrial Accumulation. Berberine is a fluorescent compound, and its localization in cells was visualized using a Nikon Eclipse TE2000U epifluorescence microscope and a fluorescein filter set (Nikon, Melville, NY). Hoechst $33342(2 \mu \mathrm{g} / \mathrm{ml})$ was added to cells $30 \mathrm{~min}$ before the end of the berberine exposure time. FCCP $(10 \mu \mathrm{M})$ was preincubated with one set of cells treated with berberine to investigate whether dissipation of mitochondrial membrane potential alters berberine accumulation. 
Labeling with Hoechst 33342, TMRM, and Calcein-AM. Before the ending of drug exposure time, cells in glass-bottom dishes were incubated with TMRM (100 nM), Hoechst $33342(1 \mu \mathrm{g} / \mathrm{ml})$, and calcein-AM ( $300 \mathrm{nM})$ for $30 \mathrm{~min}$ at $37^{\circ} \mathrm{C}$ in the dark. Due to the very low fluorescence of the probes in the extracellular media, the images were collected without replacing the cell culture media. The images were obtained using a Nikon C-1 laser scanning confocal microscope. TMRM signal was acquired using a green He-Ne laser. The calcein-AM signal was acquired using an air-cooled argon laser, and the Hoechst signal was obtained by using a violet diode laser. Differential interference contrast images using the confocal microscope were collected using the air-cooled argon laser and the appropriate detector.

Quantification of TMRM Mitochondrial Fluorescence. Cells were seeded, treated with TMRM as described above, and visualized with a Nikon Eclipse TE2000U epifluorescence microscope. Using Metamorph software (Universal Imaging, Downingtown, PA), cells were analyzed in terms of their mean TMRM fluorescence values and also in terms of the S.D. values for the fluorescence of each cell. The S.D. values were used to characterize the effects of berberine of mitochondrial TMRM florescence because they give a more precise idea of the magnitude of the difference between cytosolic and mitochondrial TMRM accumulation.

\section{Electron Microscopy of K1735-M2 Cells}

After treatment, trypsinized cells were fixed for electron microscopy by adding $3 \%$ glutaraldehyde in $0.1 \mathrm{M}$ sodium cacodylate buffer, $\mathrm{pH} 7.3$, and were incubated for $2 \mathrm{~h}$ at $4^{\circ} \mathrm{C}$. After centrifugation $(2500 \mathrm{~g}, 3 \mathrm{~min})$, pellets were washed with $0.1 \mathrm{M}$ sodium cacodylate buffer, $\mathrm{pH} 7.3$, and resuspended in $1 \% \mathrm{OsO}_{4}$ buffered with $0.1 \mathrm{M}$ sodium cacodylate, $\mathrm{pH}$ 7.3. After a 2 -h incubation, pellets were washed with cacodylate buffer, $\mathrm{pH} 7.3$, and embedded in $1 \%$ agar. Samples were then dehydrated in ethanol and embedded in Spurr's resin. Ultrathin sections were obtained with an LKB ultra-microtome Ultrotome III (GE Healthcare, Little Chalfont, Buckinghamshire, UK), stained with methanolic uranyl acetate followed by lead citrate, and examined with a JEOL Jem-100SX electron microscope (JEOL, Tokyo, Japan) operated at $80 \mathrm{kV}$. Five to 10 micrographs were taken from random fields, and mitochondrial profiles were observed. Each field contained one to two cells. By definition, mitochondrial bodies are structures that possessed morphological features of mitochondria, including a double-membrane system and inner cristae.

\section{Determination of Mitochondrial DNA Copy Number}

Total genomic nuclear and mtDNA from M2 cells was isolated using the GenElute Mammalian Genomic DNA Miniprep Kit (Sigma-Aldrich). Standard curves were generated from the control DNA sample using serial dilutions. Quantitative real-time PCR using the LightCycler system (Roche Diagnostics, Indianapolis, IN) was performed, and the following reaction components were prepared: $3.6 \mu \mathrm{l}$ of water, $0.2 \mu \mathrm{l}$ of forward primer $(0.2 \mu \mathrm{M}), 0.2 \mu \mathrm{l}$ of reverse primer $(0.2 \mu \mathrm{M})$, and $5.0 \mu \mathrm{l}$ of LightCyler (Roche Diagnostics). LightCycler mixture $(9 \mu \mathrm{l})$ was filled in the LightCycler glass capillaries, and $1 \mu \mathrm{l}$ of DNA sample $(2 \mathrm{ng})$ was added as PCR template. 5COI and 3COI are mtDNA primers (Thundathil et al., 2005), and MuRTGADD45a (5'-ACCCCGATAACGTGGTACTG-3') and MuGADD45R (5'-TGACCCGCAGGATGTTGATG-3') are mouse GADD45 genomic DNA primers that sit in exon 3. Capillaries were closed, centrifuged, and placed into the LightCycler rotor. The following LightCycler experimental run protocol was used: denaturation program $\left(95^{\circ} \mathrm{C}\right.$ for $\left.30 \mathrm{~s}\right)$, amplification and quantification program repeated 50 times $\left(95^{\circ} \mathrm{C}\right.$ for $5 \mathrm{~s}, 60^{\circ} \mathrm{C}$ for $20 \mathrm{~s}, 72^{\circ} \mathrm{C}$ for $20 \mathrm{~s}$ ), melting curve program $\left(95-45-95^{\circ} \mathrm{C}\right.$ with a final heating rate of $0.1^{\circ} \mathrm{C} / \mathrm{s}$ and a continuous fluorescence measurement), and finally a cooling step to $40^{\circ} \mathrm{C}$. The crossing points for each transcript based on the standard curves were mathematically determined.

\section{Determination of Oxidative Stress in Live Cells}

Vital imaging of oxidative stress in K1735-M2 was determined according to the protocol described by Sardão et al. (2007). Cells seeded in glass-bottom dishes were incubated with $\mathrm{CM}-\mathrm{H}_{2}$ DCFDA $(7.5 \mu \mathrm{M})$ for $1 \mathrm{~h}$ at $37^{\circ} \mathrm{C}$ in the dark. Media were then replaced by new prewarmed DMEM, and then cells were returned to the incubator for another hour. Media were then again replaced by $2 \mathrm{ml}$ of Krebs buffer $(1 \mathrm{mM} \mathrm{CaCl}, 132 \mathrm{mM} \mathrm{NaCl}, 4 \mathrm{mM} \mathrm{KCl}, 1.2 \mathrm{mM}$ $\mathrm{Na}_{2} \mathrm{HPO}_{4}, 1.4 \mathrm{mM} \mathrm{MgCl}, 6 \mathrm{mM}$ glucose, $10 \mathrm{mM}$ HEPES, $\mathrm{pH}$ 7.4). Cells were observed by epifluorescence microscopy using a Nikon Eclipse TE2000U microscope (fluorescein filter), and images were obtained using Metamorph software (Universal Imaging).

\section{Adenine Nucleotide Extraction from Cells in Culture}

An acid extraction procedure was used to evaluate the intracellular concentration of adenine nucleotides. Both adherent and nonadherent (dead) cells were collected. Adenine nucleotides were separated by reverse-phase high-performance liquid chromatography. The chromatographic apparatus was a Beckman-System Gold (Beckman Coulter, Fullerton, CA), consisting of a 126 Binary Pump Model and a 166 Variable UV detector, computer-controlled. The detection wavelength was $254 \mathrm{~nm}$, and the column was a Lichrospher 100RP-18 $(5 \mu \mathrm{m})$ from Merck (Dramstadt, Germany). An isocratic elution with $100 \mathrm{mM}$ phosphate buffer $\left(\mathrm{KH}_{2} \mathrm{PO}_{4}\right), \mathrm{pH} 6.5$, and $1 \%$ methanol was performed with a flow rate of $1.1 \mathrm{ml} / \mathrm{min}$. The required time for each analysis was 5 min. Quantification was achieved by employing ATP, ADP, and AMP standard curves.

\section{Isolation of Rat Liver Mitochondria}

Mitochondria were isolated from liver of male Wistar rats by conventional methods with slight modifications. Homogenization medium contained $250 \mathrm{mM}$ sucrose, $10 \mathrm{mM}$ HEPES, $\mathrm{pH} 7.4,1 \mathrm{mM}$ EGTA, and $0.1 \%$ fat-free bovine serum albumin (BSA). EGTA and BSA were omitted from the final washing medium, adjusted at $\mathrm{pH}$ 7.2. The mitochondrial pellet was washed twice, suspended in the washing medium, and immediately used. Protein content was determined by the biuret method (Gornall et al., 1949) calibrated with BSA.

\section{Oxygen Consumption}

Oxygen consumption of isolated liver mitochondria was polarographically monitored with a Clark oxygen electrode connected to a suitable recorder in a 1-ml thermostated, water-jacketed, closed chamber with magnetic stirring at a constant temperature of $30^{\circ} \mathrm{C}$. The standard respiratory medium consisted of $135 \mathrm{mM}$ sucrose, 65 $\mathrm{mM} \mathrm{KCl}, 2.5 \mathrm{mM} \mathrm{MgCl}_{2}, 5 \mathrm{mM} \mathrm{KH}_{2} \mathrm{PO}_{4}$, and $5 \mathrm{mM}$ HEPES, $\mathrm{pH} 7.2$. Mitochondria were suspended at a concentration of $1.5 \mathrm{mg} / \mathrm{ml}$ in the respiratory medium. Respiration was started by adding $5 \mathrm{mM}$ glutamate plus malate or $5 \mathrm{mM}$ succinate with $3 \mu \mathrm{M}$ rotenone. ADP (125 $\mathrm{nmol})$ was added to initiate state 3 respiration. Oligomycin $(1 \mu \mathrm{g})$ and FCCP $(1 \mu \mathrm{M})$ were also added to the system to inhibit passive proton flux through the ATP synthase and to uncouple respiration, respectively. Berberine was preincubated with mitochondria in the reaction medium for 2 min before the addition of the respiratory substrate.

\section{Mitochondrial Transmembrane Potential}

The mitochondrial transmembrane potential $(\Delta \Psi)$ was indirectly estimated by the mitochondrial accumulation of the lipophilic cation tetraphenylphosphonium cation $\left(\mathrm{TPP}^{+}\right)$as detected by using a $\mathrm{TPP}^{+}$-selective electrode in combination with an $\mathrm{Ag} / \mathrm{AgCl}$-saturated reference electrode. Both the $\mathrm{TPP}^{+}$electrode and the reference electrode were inserted into an open vessel with magnetic stirring and were connected to a pH meter (model 3305; Jenway, Essex, UK). The signals were fed to a potentiometric recorder (model BD 121; Kipp \& Zonen B.V., Delft, The Netherlands). No correction was made for the "passive" binding of $\mathrm{TPP}^{+}$to the mitochondrial membranes since the 
purpose of the experiments was to show relative changes in potentials rather than absolute values. Mitochondrial protein $(1.5 \mathrm{mg})$ was suspended under constant stirring in $1 \mathrm{ml}$ of reaction medium composed of $125 \mathrm{mM}$ sucrose, $65 \mathrm{mM} \mathrm{KCl}, 5 \mathrm{mM} \mathrm{KH} \mathrm{KO}_{4}, 2.5 \mathrm{mM}$ $\mathrm{MgCl}_{2}$, and $5 \mathrm{mM}$ HEPES, $\mathrm{pH} 7.4\left(30^{\circ} \mathrm{C}\right)$, supplemented with $3 \mu \mathrm{M}$ $\mathrm{TPP}^{+}$. Mitochondria were energized with $10 \mathrm{mM}$ glutamate/malate or $10 \mathrm{mM}$ succinate plus $3 \mu \mathrm{M}$ rotenone. Berberine was added before mitochondrial protein. ADP (125 nmol) was added to initiate phosphorylation. Absolute values for membrane potential (in millivolts) were determined from the equation originally proposed by Kamo et al. (1979), assuming Nernst distribution of the ion across the membrane electrode. A matrix volume of $1.1 \mu \mathrm{l} / \mathrm{mg}$ protein was assumed.

\section{Mitochondrial Swelling}

Mitochondrial osmotic volume changes were followed by the decrease of absorbance at $540 \mathrm{~nm}$ with a Jasco V-560 spectrophotometer (Jasco, Tokyo, Japan). The assays were performed in $2 \mathrm{ml}$ of the reaction media (200 mM sucrose, $10 \mathrm{mM}$ Tris-MOPS, $\mathrm{pH} 7.4,10 \mu \mathrm{M}$ EGTA, $1 \mathrm{mM} \mathrm{KH}_{2} \mathrm{PO}_{4}, 1.5 \mu \mathrm{M}$ rotenone, and $2.5 \mathrm{mM}$ succinate), 1.5 $\mathrm{mg}$ of protein with constant stirring, at $30^{\circ} \mathrm{C}$. Calcium $(20 \mu \mathrm{M})$ was added to the preparation $1 \mathrm{~min}$ after to the start of the experiment. Cyclosporin A $(1 \mu \mathrm{M})$ was added to the mitochondrial preparation before the addition of calcium to inhibit the mitochondrial permeability transition. Berberine was preincubated with the mitochondrial preparation for $2 \mathrm{~min}$.

\section{Mitochondrial Calcium Loading}

Extramitochondrial free $\mathrm{Ca}^{2+}$ was assayed by using the hexapotassium salt of the fluorescence probe Calcium Green 5-N (100 nM) (Rajdev and Reynolds, 1993). In brief, heart mitochondria $(0.4 \mathrm{mg})$ were suspended in $2 \mathrm{ml}$ of buffer containing $200 \mathrm{mM}$ sucrose, $10 \mathrm{mM}$ Tris, $10 \mu \mathrm{M}$ EGTA (to complex basal calcium), $1 \mathrm{mM} \mathrm{KH_{2 }} \mathrm{PO}_{4}, 2 \mu \mathrm{M}$ rotenone, and $4 \mathrm{mM}$ succinate. Fluorescence was continuously recorded in a water-jacketed cuvette holder at $30^{\circ} \mathrm{C}$ using a PerkinElmer LS-55 fluorescence spectrometer (PerkinElmer Life and Analytical Sciences, Boston, MA) with excitation and emission wavelengths of 506 and $531 \mathrm{~nm}$, respectively. Slits used were $5 \mathrm{~nm}$ for both excitation and emission wavelengths.

\section{Measurements of Mitochondrial Reactive Oxygen Species Production}

Intramitochondrial oxidative stress was assessed by using the probe $\mathrm{CM}-\mathrm{H}_{2} \mathrm{DCFDA}$. Isolated mitochondria were incubated with CM- $\mathrm{H}_{2}$ DCFDA ( $4 \mathrm{nmol} / \mathrm{mg}$ protein) for $30 \mathrm{~min}$ under constant circular motion. Mitochondria were then centrifuged $\left(8000 \mathrm{~g}\right.$ at $\left.4^{\circ} \mathrm{C}\right)$ and suspended in $1 \mathrm{ml}$ of an ice-cold isolation medium containing 250 $\mathrm{mM}$ sucrose and $10 \mathrm{mM}$ HEPES-KOH, pH 7.4. Subsequently, mitochondria $(1 \mathrm{mg})$ were suspended in standard reaction media and supplemented with glutamate/malate $(2 \mathrm{mM})$ and with the different berberine concentrations tested. Rotenone $(1.5 \mu \mathrm{M})$ and succinate ( $2.5 \mathrm{mM}$ ) were added during different time points. DCF fluorescence was continuously recorded in a water-jacketed cuvette holder at $30^{\circ} \mathrm{C}$ using a PerkinElmer LS-50B fluorescence spectrometer with excitation and emission wavelengths of 485 and $520 \mathrm{~nm}$ (5-nm slits), respectively.

\section{Mitochondrial ATPase Activity}

The effect of berberine on mitochondrial ATPase was observed by two distinct methods. First, the activity of mitochondrial ATPase was evaluated thorough detection of $\mathrm{pH}$ changes occurring during ATP hydrolysis, as described previously (Carvalho et al., 1974). Mitochondria (1.5 mg of protein) were incubated in $1 \mathrm{ml}$ of reaction media (135 mM sucrose, $65 \mathrm{mM} \mathrm{KCL}, 2.5 \mathrm{mM} \mathrm{MgCl}_{2}, 5 \mathrm{mM}$ $\mathrm{KH}_{2} \mathrm{PO}_{4}$ ), $\mathrm{pH} 7.2$. Reaction was initiated by the addition of $3 \mathrm{mM}$ ATP. Oligomycin was used as a selective inhibitor of ATPase $\left(F_{O}\right.$ unit) and completely abolished $\mathrm{pH}$ alterations. Known concentrations of $\mathrm{KOH}$ were used to calibrate the system.
ATPase activity was also measured by the ATP-induced generation of transmembrane potential $(\Delta \psi)$ by using a $\mathrm{TPP}^{+}$-selective electrode. Mitochondria (1.5 of mg protein) were incubated in $1 \mathrm{ml}$ of reaction media ( $125 \mathrm{mM}$ sucrose, $65 \mathrm{mM} \mathrm{KCL}, 2.5 \mathrm{mM} \mathrm{MgCl}_{2}, 5 \mathrm{mM}$ $\mathrm{KH}_{2} \mathrm{PO}_{4}, 5 \mathrm{mM}$ HEPES), $\mathrm{pH} 7.4$ at $30^{\circ} \mathrm{C}$. The media were supplemented with $3 \mu \mathrm{M} \mathrm{TPP}^{+}$and $3 \mu \mathrm{M}$ rotenone. Reaction was started by $3 \mu \mathrm{M}$ ATP. Oligomycin was used as a selective inhibitor of ATP synthase $\left(\mathrm{F}_{\mathrm{O}}\right.$ unit).

\section{Statistical Analysis}

Data are expressed as means \pm S.E.M. and evaluated by one-way analysis of variance followed by Bonferroni multiple comparison tests. Differences were considered significant if the $p$ value was lower than 0.05 .

\section{Results}

Effect of Berberine in K1735-M2 Cell Line Proliferation. To investigate whether berberine inhibits cell proliferation, K1735-M2 mouse melanoma cells were incubated in the absence and presence of increasing concentrations of drug $(5,10,25,75$, and $100 \mu \mathrm{M})$ for $24,48,72$, and $96 \mathrm{~h}$. As shown in Fig. 2, berberine has a dose-time-dependent effectinhibiting cell proliferation. Within $24 \mathrm{~h}$ of drug treatment, cell proliferation does not seem to be affected. However, after $48 \mathrm{~h}$ of incubation time, the growth profile changes, and an inhibitory effect is observed for all drug concentrations tested. Approximately 50\% of growth inhibition is observed for 72 and $96 \mathrm{~h}$ of drug exposure. Berberine effect on cell proliferation is more dependent on time exposure than on the drug concentration because for $96 \mathrm{~h}$ of drug exposure, the majority of drug concentrations inhibit cell proliferation. As described elsewhere, the present technique cannot conclude whether the effect of berberine is due to an increase of cell death or due to cell cycle arrest.

Berberine Accumulates in Mitochondria of K1735-M2 Cells. To evaluate the intracellular location of berberine accumulation, K1735-M2 cells were incubated with one selected berberine concentration $(25 \mu \mathrm{M})$ during $6 \mathrm{~h}$ and then examined by epifluorescence microscopy. In Fig. 3A, clusters of green

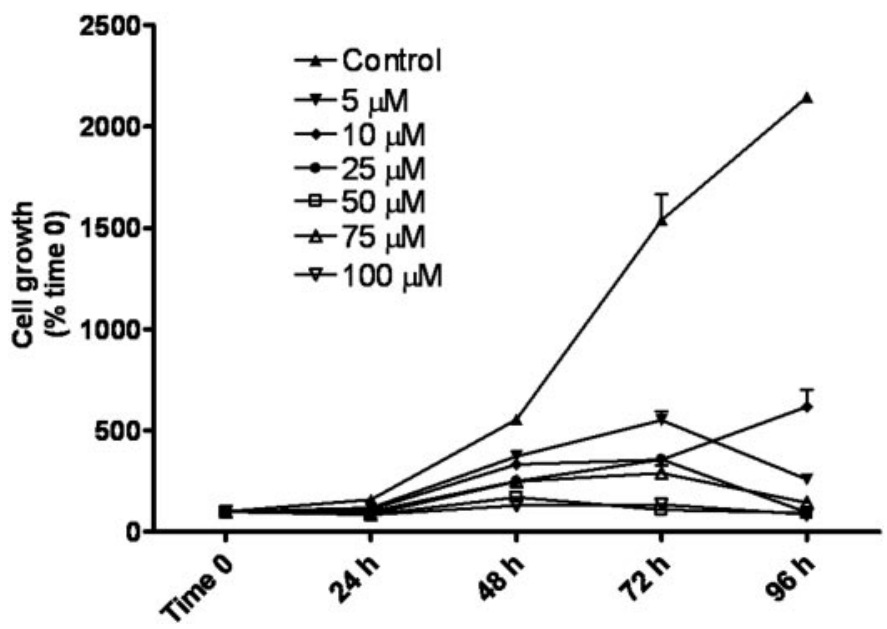

Fig. 2. Antiproliferative effect of berberine in K1735-M2 mouse melanoma cell proliferation profile. Cells $\left(1.0 \times 10^{5}\right)$ were incubated and drugged $24 \mathrm{~h}$ later with a range of concentrations up to $100 \mu \mathrm{M}$ during 24 , 48, 72, and $96 \mathrm{~h}$. Cell proliferation was accessed at each time by the SRB colorimetric assay as described under Materials and Methods and plotted against time of exposure and concentration of berberine. Data presented as means \pm S.E.M. of four different experiments. 

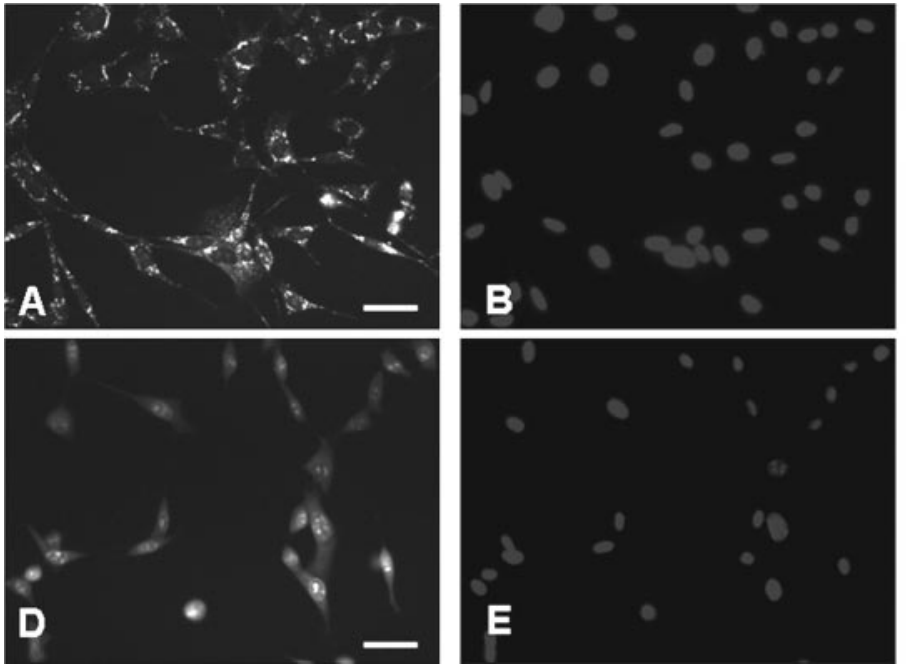

fluorescence in the cell cytoplasm are observed demonstrating intracellular berberine accumulation. A magnification of some of the cells (Fig. 3, C and F) shows that the clusters resemble mitochondria. To confirm berberine localization, an indirect method using FCCP, a mitochondrial uncoupler, was chosen since colocalization with other mitochondrial probes (viz. TMRM or Mitotracker Red) interfered with berberine localization and self-fluorescence (data not shown). When FCCP was used to dissipate the mitochondrial electric potential, the results demonstrated that no mitochondrial berberine accumulation could be detected in the presence of FCCP (Fig. 3D). The observation confirms that berberine is accumulated electrophoretically, i.e., with a dependence on the mitochondrial transmembrane electric potential. Interestingly, when mitochondrial membrane potential was collapsed with FCCP, nuclear berberine fluorescence occurs (Fig. 3E), which suggests that in the absence of an electric gradient, berberine can be accumulated in the nuclei.

Berberine Causes Mitochondrial Damage on K1735-M2 Melanoma Cells. To investigate alterations of

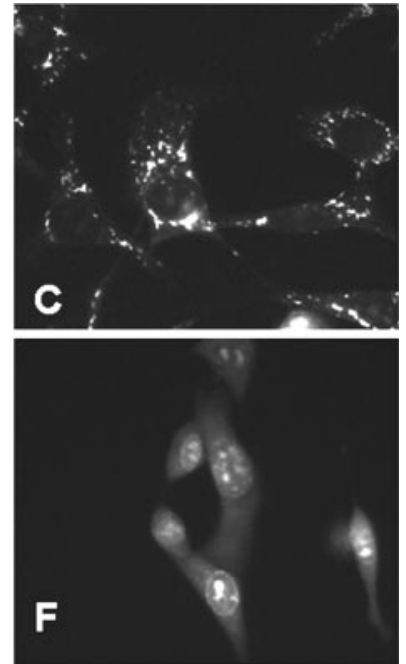

Fig. 3. Berberine accumulation in mitochondria of K1735-M2 mouse melanoma cells after $6 \mathrm{~h}$ of drug exposure evaluated by epifluorescence microscopy. Berberine presents green fluorescence, which allows identification of the intracellular site of drug accumulation. A, accumulation of $25 \mu \mathrm{M}$ berberine in control cells (berberine self-fluorescence). B, Hoechst 33342 labeling of field shown in A. C, magnification of some of the cells in A. D, no berberine signal is observable when cells were preincubated with $10 \mu \mathrm{M}$ FCCP, a mitochondrial uncoupler. E, Hoechst 33342 labeling of field shown in D. F, magnification of some cells shown in D. Cells were observed with an epifluorescence microscope by using the fluorescein isothiocyanate filter. Nuclei were labeled with Hoechst 33342. Bar, $30 \mu \mathrm{m}$.

mitochondrial morphology induced by berberine, cells were treated with berberine $(5-50 \mu \mathrm{M})$ for 6 and $24 \mathrm{~h}$ (Fig. 4). Forty-five minutes before the end of the incubation period, cells were incubated with TMRM. Larger concentrations were not tested due to the strong interference of berberine self-fluorescence. It was observable that alterations in mitochondrial membrane potential (decreased mitochondrial TMRM signal) and morphology (mitochondrial fragmentation) are already observed for $6 \mathrm{~h}(25$ and $50 \mu \mathrm{M})$. For $24 \mathrm{~h}$, the effects are greatly enhanced, and alterations appear already for $10 \mu \mathrm{M}$ berberine. Measurements up to $96 \mathrm{~h}$ were already performed using the same protocol. For such long time points, a complete dissipation of TMRM signal was observed in most cells (data not shown). Only a few cells showed small round (instead of filamentous) mitochondria still retaining TMRM (data not shown).

To explore in detail mitochondrial alterations caused by berberine, we mostly focused in one berberine concentration (25 $\mu \mathrm{M}$ ) because the objective was to cause notorious mitochondrial damage with concentrations not lacking relevance

\section{6 hours}

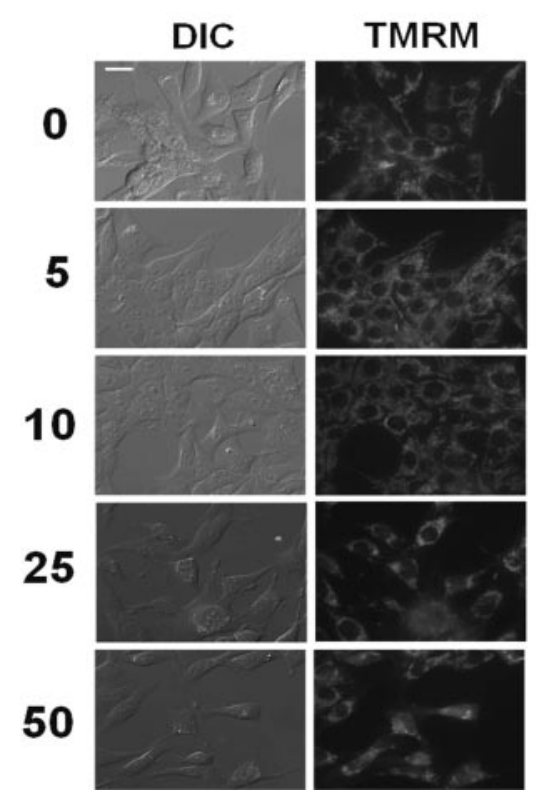

\section{4 hours}

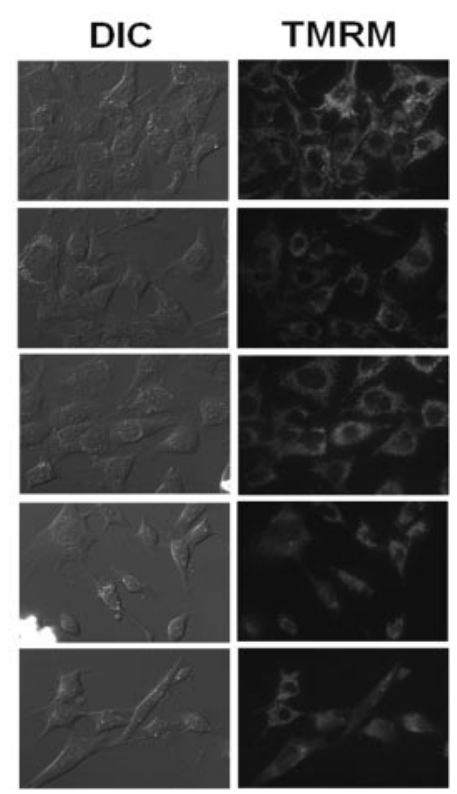

Fig. 4. Dose-dependent effects of berberine on mitochondrial TMRM accumulation and overall morphology. Cells were incubated with crescent concentrations (numbers on the left, in micromolar) of berberine for 6 and $24 \mathrm{~h}$. Fortyfive minutes before the end of the incubation time, cells were incubated with the mitochondrial fluorometric probe TMRM, which accumulates according to the mitochondrial electric membrane potential. The most noticeable alterations, which appear dependent on the incubation time and berberine concentration, are loss of mitochondrial TMRM accumulation (reflecting mitochondrial depolarization) and breakage of mitochondrial filamentous. White bar, $15 \mu \mathrm{m}$. 
in in vivo systems. Cells incubated with berberine were fluorescently labeled with Hoechst 33342 and TMRM. Mitochondrial accumulation of TMRM results in red fluorescence. Because berberine also presents red fluorescence, a conflict between both signals could be a problem. However, TMRM has a higher fluorescence quantum yield, so the contribution of berberine fluorescence is nonsignificant. Figure 5, A and B, show that after $24 \mathrm{~h}$ of treatment, the filamentous mitochondrial network is dismantled, and mitochondria appear to be smaller and rounder in shape. Alterations in mitochondrial structure occur with intact cell viability, as observed by intracellular calcein-AM accumulation and TMRM fluorescence (Fig. 5C). Mitochondrial fragmentation did not increase the apparent number of mitochondrial bodies as observed by electron microscopy (EM). In fact, by visualizing several fields from each treatment group, a lower number of mitochondrial bodies was observed after berberine treatment, although determination of mitochondrial mass by EM warrants several notes of caution. By comparing Fig. 5, A with B, it is also observable that loss of mitochondrial TMRM fluorescence accompanies fragmentation even for $6 \mathrm{~h}$ of exposure (Fig. 5, I and J). Berberine (50 $\mu \mathrm{M})$ was used to investigate whether a dose-dependent effect could be found. In fact, the depolarization effect obtained with the higher concentration was not dissimilar from the result obtained with the lower concentration. Figure 5F shows control condensed mitochondria where cristae can be easily observed. In contrast, most mitochondrial bodies lost their typical shape, swelled, and appeared to lose their cristae after a 24-h incubation period with berberine, although different degrees of damage were observable (Fig. 5, D-H). The apparent decrease in mitochondrial numbers by electron microscopy was also supported by the finding that mtDNA copy number decreases when cells are treated with $25 \mu \mathrm{M}$ berberine for 24 and $48 \mathrm{~h}$ (Fig. $5 \mathrm{~K}$ ). Surprisingly, when that maximum berberine concentration used in proliferation studies $(100 \mu \mathrm{M})$ was used, no decrease in mtDNA copy number occurred. The normal processes that occur in an apoptotic cell, such as nucleus/chromatin condensation, membrane blebbing, and the formation of apoptotic bodies, was not observed at the concentrations of berberine used in this study (up to $100 \mu \mathrm{M}$; data not shown).

Berberine Increases Intracellular Oxidative Stress. To test whether berberine increases oxidative stress, cells were incubated with the drug $(25 \mu \mathrm{M})$ for 6 and $24 \mathrm{~h}$. Fortyfive minutes before the end of incubation period, cells were incubated with Hoechst 33342, TMRM, and CM-H ${ }_{2}$ DCFDA, a fluorescent probe for oxidative stress. Figure 6 shows that $6 \mathrm{~h}$ of exposure is not enough to cause a significant increase in intracellular oxidative stress as opposed to $24 \mathrm{~h}$ of drug exposure when an increase of probe fluorescence was observed in cells treated with $25 \mu \mathrm{M}$ berberine. We also confirmed that the mitochondrial depolarization precedes the detection of oxidative stress.

Berberine Decreases Energy Charge in K1735-M2 Cells. Berberine decreases cellular energy charge, ([ATP] + $0.5[\mathrm{ADP}]) /([\mathrm{ATP}]+[\mathrm{ADP}]+[\mathrm{AMP}])$, with the greatest decreases occurring after $72 \mathrm{~h}$ (Table 1 ). The ratio of ATP/ADP was also altered by berberine when cells were incubated for $24 \mathrm{~h}$ (Table 1). Interestingly, for longer exposure periods, the effects of berberine on the ATP/ADP ratio are decreased. In fact, for $72 \mathrm{~h}$, the ratio is not dissimilar from the control. Regarding the specific type of adenine nucleotide affected by berberine, the results (Table 2) demonstrate that ATP quantity decreases within $24 \mathrm{~h}$ in the presence of $25 \mu \mathrm{M}$ berberine. As opposed to the unchanged ATP/ADP ratio found for $72 \mathrm{~h}$, there is a statistically significant change in ATP concentration between control and treated cells. The unchanged ratio described in Table 1 is caused by the simultaneous decrease of ADP, which is also accompanied by increased AMP levels. The overall results indicate that both ATP and ADP are decreased by berberine treatment, whereas AMP concentrations increase. FCCP, a mitochondrial uncoupler, shows similar results to that of berberine, suggesting a possible equivalence of targets and mechanisms of action. None of the drugs or concentrations tested altered the total number of adenine nucleotides.

Berberine Affects Mitochondrial Oxygen Consumption. The effect of berberine on mitochondrial oxygen consumption with both glutamate/malate and succinate as substrates is described in Tables 3 and 4, respectively. Under the range of concentration of up to $66.7 \mathrm{nmol}$ berberine/mg protein, berberine decreases the respiratory control ratio (RCR) for both respiratory substrates (absolute values of control, $6.0 \pm 0.67$ for glutamate/malate and $4.1 \pm 0.43$ for succinate) . However, the decrease is more evident when the substrate for complex I is used (approximately 80 versus 50\% when succinate is used at the highest berberine concentration). The ADP/O ratio remained unchanged for both types of substrate except for the higher concentrations (33.35 and 66.7 $\mathrm{nmol}$ berberine/mg protein), where a significant decrease can be observed (absolute values of control, $2.2 \pm 0.21$ for glutamate/malate and $1.6 \pm 0.15$ for succinate). The results suggest an effect on the electron transfer chain (predominantly at the complex I level) but also a possible interference in the mitochondrial phosphorylation system. The values for the $\mathrm{RCR}$ of the control group denote a good mitochondrial preparation, which is further confirmed by the $\mathrm{ADP} / \mathrm{O}$ values. In the presence of the uncoupler FCCP, respiration is progressively decreased by berberine regardless of the drug concentration or respiratory substrate. However, it must be stressed that mitochondrial respiratory state 3 is more strongly inhibited compared with uncoupled respiration when mitochondria are energized by complex I substrates as observed in Fig. 7A. When liver mitochondria were energized with a complex II substrate, respiratory state 3 decreased in a similar fashion to uncoupled respiration. When glutamate/ malate is used, mitochondrial respiratory state 4 is not altered except for the highest berberine concentration used $(100 \mu \mathrm{M})$. When mitochondria are energized by succinate, an increase of oxygen consumption in mitochondrial respiratory state 4 is observed instead, but this effect is abolished when oligomycin is added, suggesting a possible increased passive flux of protons through the $\mathrm{F}_{\mathrm{O}}$ subunit of the ATP synthase. Stimulation of respiration during state 4 is not observed when mitochondria are energized by glutamate/malate because more severe inhibition of the respiratory chain may hide the effect.

Berberine Affects the Generation of Mitochondrial Membrane Potential. When analyzing the effects of berberine on mitochondrial $\Delta \Psi$ generation (Tables 5 and 6; Fig. 8 ), only the highest concentrations have significant effects on the maximal $\Delta \Psi$ generated. The differences are more drastic when parameters related to the phosphorylation system are analyzed, namely the depolarization induced by ADP and the 

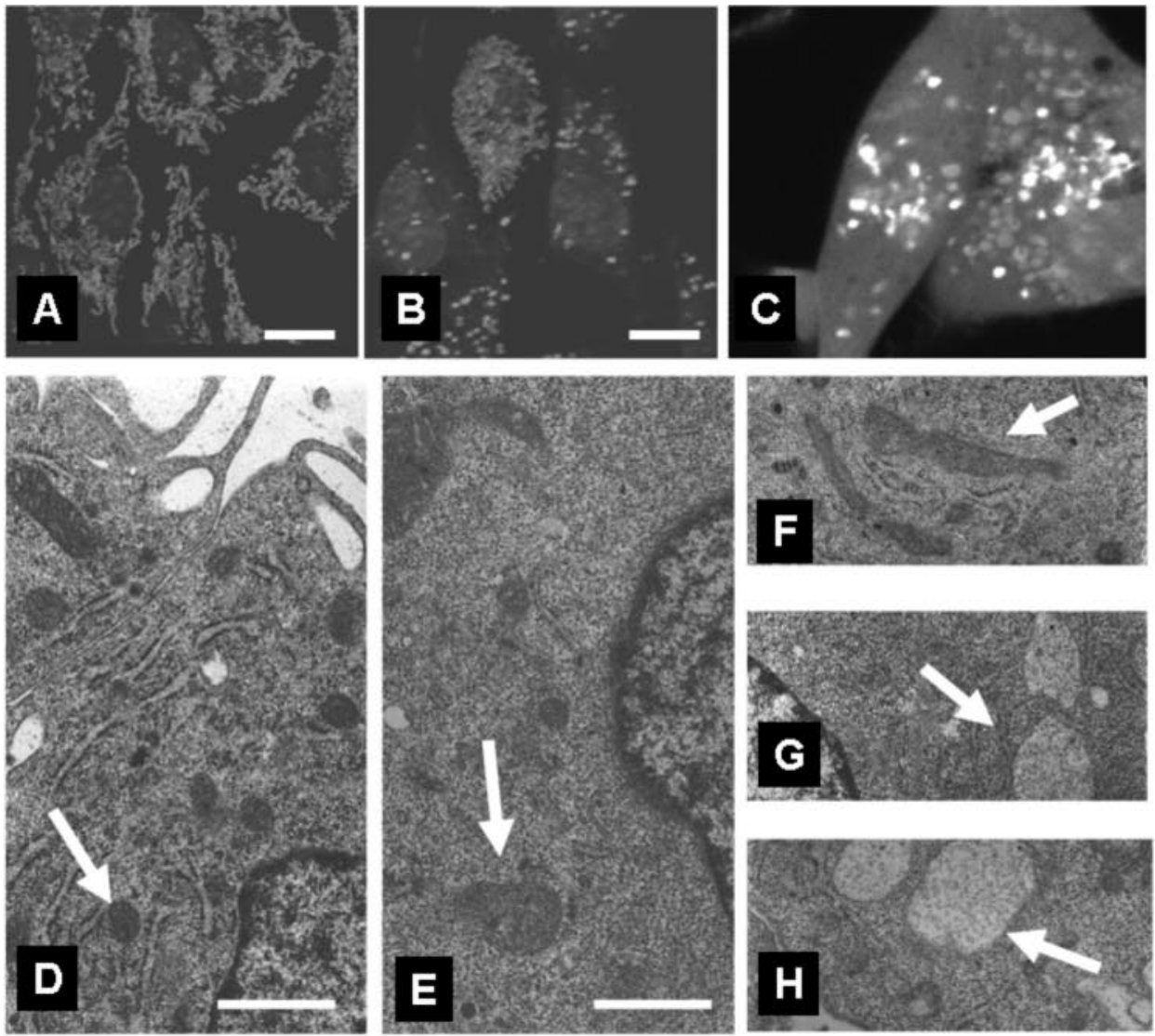

6 hours
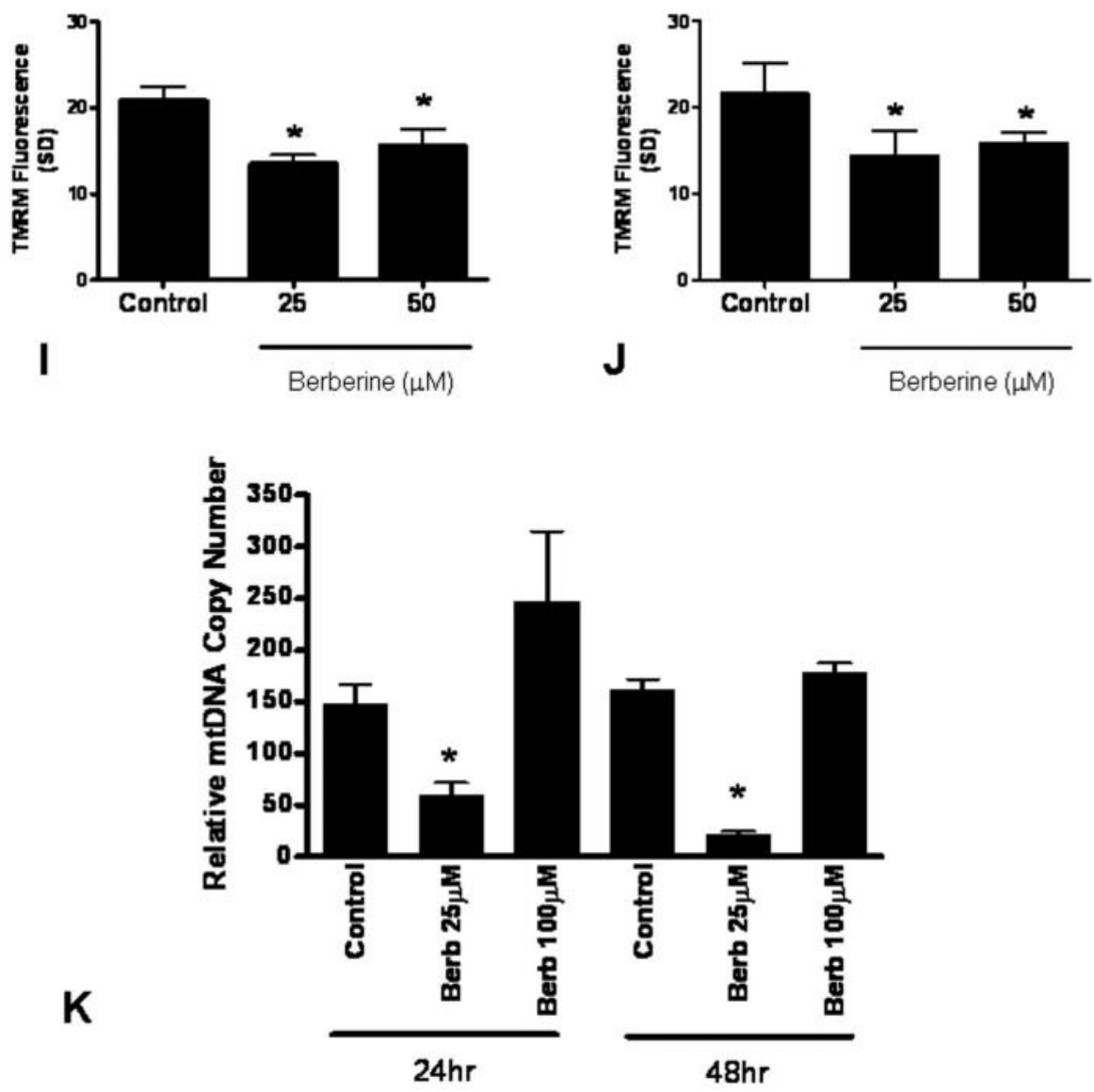

Fig. 5. Mitochondrial alterations induced by berberine. The effects of berberine on mitochondrial structure were evaluated by using confocal and electron microscopy MtDNA copy numbers were evaluated by using real-time PCR. A and B, confocal microscopy of K1735-M2 cells treated with vehicle (A) and $25 \mu \mathrm{M}$ berberine (B) during $24 \mathrm{~h}$. White bar, $15 \mu \mathrm{m}$. Live cells were labeled with the fluorescent probes TMRM (mitochondria) and Hoechst 33342 (nuclei) for $30 \mathrm{~min}$ before observation with a confocal microscope. $\mathrm{C}$, detail of a cell treated with $25 \mu \mathrm{M}$ berberine during $24 \mathrm{~h}$, where fragmented and round mitochondria labeled with TMRM can be observed. Hoechst 33342 (nucleus) and calcein-AM (cytoplasm) were the two other probes used. $\mathrm{Cy}$ toplasmic calcein granules are also observable, although their origin has yet to be identified. D and E, electron microscopy (white bars, $5 \mu \mathrm{m}$ ) showing K1735-M2 cells treated with vehicle (D) and $25 \mu \mathrm{M}$ berberine (E) during $24 \mathrm{~h}$. White arrow, mitochondrial bodies. $\mathrm{F}$ to $\mathrm{H}$, electron microscopy showing K1735-M2 cells treated with vehicle (F), $10 \mu \mathrm{M}(\mathrm{G})$, and $25 \mu \mathrm{M}$ berberine $(\mathrm{H})$ during $24 \mathrm{~h}$. White arrow, mitochondrial bodies. All three panels are the same magnification. I and J, evaluation of TMRM fluorescence in cells treated with vehicle and 25 and $50 \mu \mathrm{M}$ berberine for 6 (I) and 24 (J) h. Quantification of cell fluorescence was made as described under Materials and Methods. *, $p<0.05$ versus control. K, mtDNA copy number of cells treated with vehicle or 25 or $100 \mu \mathrm{M}$ berberine. Relative mtDNA copy numbers were determined as described under Materials and Methods. 

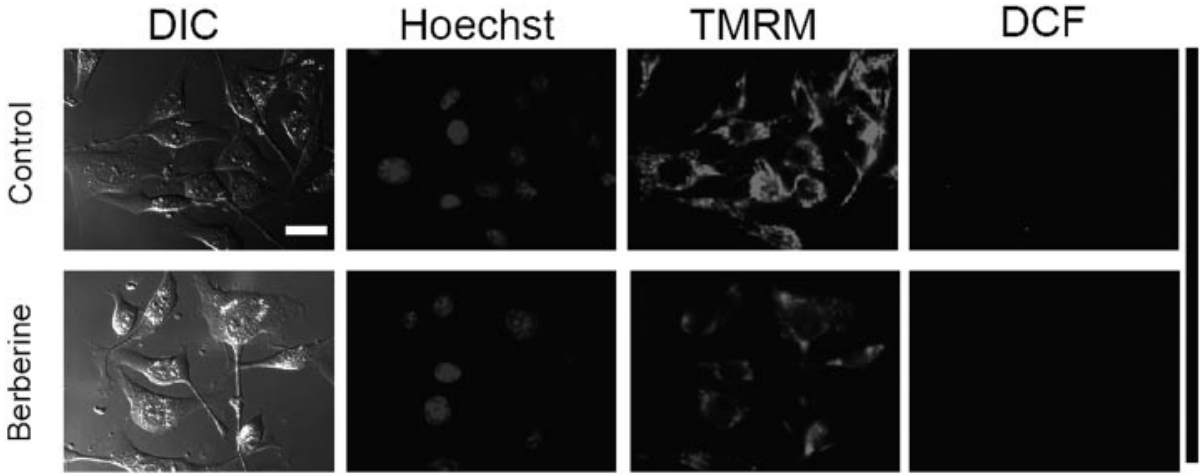

$\frac{a}{\text { ปิ }}$
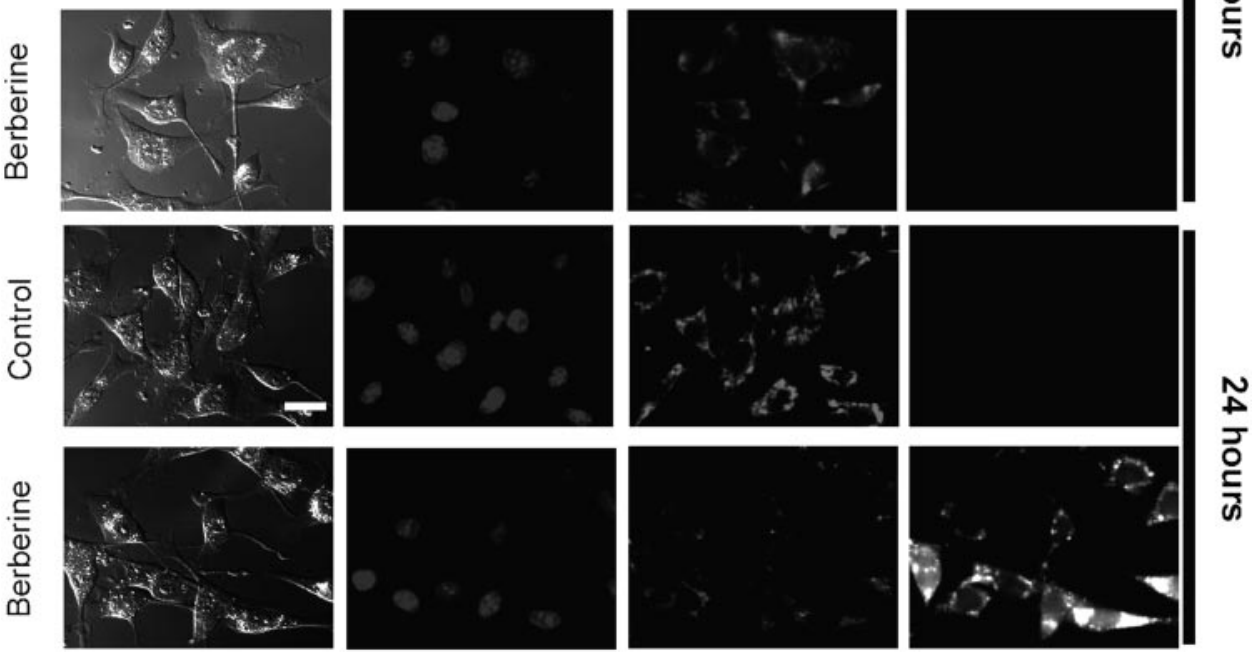

Fig. 6. Berberine induced mitochondrial depolarization and increased oxidative stress in K1735-M2 mouse melanoma cells. Cells were incubated with $25 \mu \mathrm{M}$ berberine for 6 or $24 \mathrm{~h}$. Forty-five minutes before the end of the incubation period, the fluorescent probes TMRM (red, mitochondria), Hoechst 33342 (blue, nuclei), and $\mathrm{CM}-\mathrm{H}_{2} \mathrm{DCFDA}$ (green, oxidative stress) were incubated with cells and imaged with a Nikon Eclipse 3000 epifluorescence microscope.

TABLE 1

Effects of berberine in the energy charge and ATP/ADP ratio in K1735-M2 mouse melanoma cells

FCCP, a mitochondrial uncoupler, was added as a positive control. Energy charge was calculated as $([\mathrm{ATP}]+0.5[$ ADP $]) /([\mathrm{ATP}]+[\mathrm{ADP}]+[\mathrm{AMP}])$. Data are means \pm S.E.M of at least four different preparations.

\begin{tabular}{|c|c|c|c|c|c|c|}
\hline & \multirow{2}{*}{ Control } & \multicolumn{4}{|c|}{ Berberine } & \multirow{2}{*}{$\operatorname{FCCP}(10 \mu \mathrm{M})$} \\
\hline & & $10 \mu \mathrm{M}$ & $25 \mu \mathrm{M}$ & $50 \mu \mathrm{M}$ & $100 \mu \mathrm{M}$ & \\
\hline \multicolumn{7}{|c|}{ Energy charge } \\
\hline $72 \mathrm{~h}$ & $0.52 \pm 0.06$ & $0.27 \pm 0.04^{*}$ & $0.23 \pm 0.03^{*}$ & $0.22 \pm 0.04 *$ & $0.25 \pm 0.03^{*}$ & $0.30 \pm 0.04^{*}$ \\
\hline \multicolumn{7}{|c|}{ ATP/ADP } \\
\hline $24 \mathrm{~h}$ & $1.43 \pm 0.26$ & $0.88 \pm 0.13^{*}$ & $0.76 \pm 0.10^{*}$ & $0.63 \pm 0.04 *$ & $0.64 \pm 0.07^{*}$ & $0.80 \pm 0.06^{*}$ \\
\hline
\end{tabular}

$* p<0.05$ vs. control for each time of incubation.

phosphorylation lag phase. The effects are observable for both substrates. It should be noted that for higher drug concentrations, mitochondria do not recover their normal $\Delta \Psi$ values after $\mathrm{ADP}$ addition. The results again suggest that the effects of berberine on isolated mitochondrial fractions are most evident when mitochondria are challenged to increase their respiration rate, either by using ADP or FCCP.

Berberine Stimulates the MPT on Isolated Rat Liver Mitochondria. One of the effects of MPT pore opening is mitochondrial swelling due to osmotic equilibrium between the matrix and the external compartment, leading to water influx. The effect of berberine on $\mathrm{Ca}^{2+} /$ phosphate-induced mitochondrial swelling was studied by measuring the changes in the suspension absorbance at $540 \mathrm{~nm}$ in a sucrosebased media. Figure 9 shows that berberine in a range up to $133.2 \mathrm{nmol} / \mathrm{mg}$ protein increases swelling of isolated liver mitochondria in the presence of $20 \mu \mathrm{M}$ calcium. Surprisingly, the mitochondrial swelling rate augmented by berberine does not appear to be dose-dependent because at higher concentrations, swelling slows without a decrease in amplitude (Table 7). These results were confirmed by oxygen consumption when calcium was added to mitochondria energized with succinate (data not shown)., The MPT pore inhibitor CsA (Broekemeier et al., 1989) was able to prevent mitochondrial swelling in the presence of berberine, confirming that this effect is caused by the induction of the MPT pore.

Berberine Decreases Mitochondrial Calcium Loading Capacity. To confirm that berberine induces MPT pore opening, we evaluated mitochondrial calcium loading capacity in the presence of this alkaloid. Extramitochondrial calcium levels were followed by using the fluorescence probe Calcium Green 5N. Shortly after an increase in probe fluorescence due to calcium addition, fluorescence decreased in all conditions tested, indicating mitochondrial calcium uptake. However, berberine, in a dose-dependent fashion (Fig. 10, lines 1-3), decreased calcium accumulation compared with controls. When mitochondria were preincubated with CsA, calcium-induced calcium release in the presence of berberine was inhibited. The data confirm that berberine decreases mitochondrial calcium loading capacity through increased MPT pore induction.

Berberine Increases Reactive Oxygen Species Production on Isolated Mitochondria. To determine whether the increase in oxidative stress observed in berberine-treated cells 
TABLE 2

Effects of berberine on adenine nucleotides levels of K1735-M2 mouse melanoma cells

Cells $\left(1.0 \times 10^{5}\right)$ were treated with berberine in a range up to $100 \mu \mathrm{M}$ at different incubation times. FCCP, a mitochondrial uncoupler, was added as a positive control. Adenine nucleotides quantification was realized as described under Materials and Methods, and data are described as percentage of total nucleotides. Data are means \pm S.E.M. of at least four different preparations.

\begin{tabular}{|c|c|c|c|c|c|c|}
\hline & \multirow{2}{*}{ Control } & \multicolumn{4}{|c|}{ Berberine } & \multirow{2}{*}{$\operatorname{FCCP}(10 \mu \mathrm{M})$} \\
\hline & & $10 \mu \mathrm{M}$ & $25 \mu \mathrm{M}$ & $50 \mu \mathrm{M}$ & $100 \mu \mathrm{M}$ & \\
\hline \multicolumn{7}{|c|}{ Total nucleotides (pmol/mg protein) } \\
\hline $24 \mathrm{~h}$ & $1343.8 \pm 268.1$ & $1731.4 \pm 207.1$ & $2001.1 \pm 249.6$ & $2184.0 \pm 377.1$ & $1834.9 \pm 460.1$ & $2059.3 \pm 225.7$ \\
\hline \multirow{2}{*}{\multicolumn{7}{|c|}{$\operatorname{ATP}(\%)$}} \\
\hline & & & & & & \\
\hline $24 \mathrm{~h}$ & $30.2 \pm 2.8$ & $20.8 \pm 3.1$ & $18.2 \pm 2.8^{*}$ & $15.3 \pm 3.1^{*}$ & $13.8 \pm 2.1^{*}$ & $15.8 \pm 2.4^{*}$ \\
\hline $48 \mathrm{~h}$ & $38.3 \pm 3.8$ & $28.0 \pm 3.6$ & $21.5 \pm 3.3^{*}$ & $17.2 \pm 2.7^{*}$ & $15.8 \pm 3.4^{*}$ & $18.8 \pm 2.6^{*}$ \\
\hline $24 \mathrm{~h}$ & $25.0 \pm 2.9$ & $24.1 \pm 1.3$ & $23.9 \pm 1.5$ & $23.7 \pm 3.3$ & $21.3 \pm 3.2$ & $19.3 \pm 1.7$ \\
\hline $48 \mathrm{~h}$ & $26.9 \pm 1.3$ & $24.6 \pm 1.5$ & $22.3 \pm 2.2$ & $20.3 \pm 2.5$ & $18.2 \pm 1.6^{*}$ & $18.1 \pm 2.1^{*}$ \\
\hline $72 \mathrm{~h}$ & $25.2 \pm 2.5$ & $14.5 \pm 2.5^{*}$ & $9.1 \pm 2.4^{*}$ & $8.4 \pm 1.6^{*}$ & $12.6 \pm 1.5^{*}$ & $20.8 \pm 2.5$ \\
\hline \multicolumn{7}{|c|}{$\operatorname{AMP}(\%)$} \\
\hline $24 \mathrm{~h}$ & $47.5 \pm 3.7$ & $55.0 \pm 3.3$ & $57.9 \pm 3.8$ & $61.0 \pm 6.4$ & $67.9 \pm 5.4^{*}$ & $65.0 \pm 4.0$ \\
\hline $48 \mathrm{~h}$ & $36.8 \pm 3.7$ & $47.4 \pm 4.0$ & $56.2 \pm 4.5^{*}$ & $62.4 \pm 4.7^{*}$ & $65.9 \pm 4.6^{*}$ & $63.2 \pm 4.0^{*}$ \\
\hline $72 \mathrm{~h}$ & $43.0 \pm 1.68$ & $65.5 \pm 5.3^{*}$ & $73.6 \pm 3.4^{*}$ & $73.4 \pm 3.7^{*}$ & $69.2 \pm 3.1^{*}$ & $59.1 \pm 5.0$ \\
\hline
\end{tabular}

$* p<0.05$ vs. control for each incubation time.

\section{TABLE 3}

Effects of berberine on mitochondrial respiratory parameters energized by glutamate/malate

Data represent percentage control. Mitochondria $\left(1.5 \mathrm{mg}\right.$ ) were incubated in $1 \mathrm{ml}$ of respiration media (see Materials and Methods) at $30^{\circ} \mathrm{C}$. State 4 was measured in the presence of $5 \mathrm{mM}$ glutamate plus malate. $\mathrm{ADP}(125 \mathrm{nmol})$ was added to induce state 3 respiration. Oligomycin $(1 \mu \mathrm{g})$ and $\mathrm{FCCP}(1 \mu \mathrm{M})$ were also added to the system to inhibit passive flux through the ATP synthase and to uncouple respiration. The RCR was calculated as the ratio between state 3 and state 4 respiration. The ADP/O was calculated as the number of nanomoles of ADP phosphorylated by nanoatoms of oxygen consumed during ADP phosphorylation. Data are means \pm S.E.M. of four to five different preparations. Control absolute values are expressed as nanoatoms of oxygen per minute per milligram of protein. Other values are expressed as percent control values; n.m., not measurable.

\begin{tabular}{|c|c|c|c|c|c|}
\hline Berberine & Control & $\begin{array}{l}6.7 \mathrm{nmol} / \mathrm{mg} \\
\text { Protein }\end{array}$ & $\begin{array}{l}16.7 \mathrm{nmol} / \mathrm{mg} \\
\text { Protein }\end{array}$ & $\begin{array}{l}33.4 \mathrm{nmol} / \mathrm{mg} \\
\text { Protein }\end{array}$ & $\begin{array}{c}66.7 \mathrm{nmol} / \mathrm{mg} \\
\text { Protein }\end{array}$ \\
\hline State 3 & $59.3 \pm 3.8$ & $83.2 \pm 3.0$ & $57.8 \pm 6.6^{*}$ & $33.4 \pm 4.8 *$ & $14.7 \pm 4.7^{*}$ \\
\hline $\mathrm{RCR}$ & $6.0 \pm 2.1$ & $76.3 \pm 6.3^{*}$ & $66.0 \pm 7.2^{*}$ & $30.0 \pm 6.2 *$ & $22.9 \pm 5.9^{*}$ \\
\hline $\mathrm{ADP} / \mathrm{O}$ & $2.2 \pm 0.7$ & $96.4 \pm 9.2$ & $93.3 \pm 3.3$ & n.m. & n.m. \\
\hline Oligomycin & $7.4 \pm 3.0$ & $111.6 \pm 9.3$ & $78.5 \pm 16.2$ & $79.2 \pm 13.7$ & $65.3 \pm 5.8$ \\
\hline FCCP & $68.2 \pm 6.7$ & $83.8 \pm 4.1$ & $73.9 \pm 5.2^{*}$ & $61.8 \pm 6.49^{*}$ & $56.4 \pm 11.4 *$ \\
\hline
\end{tabular}

$* p<0.05$ vs. control.

TABLE 4

Effects of berberine on mitochondrial respiratory parameters energized by succinate

Data represent percentage against control. Experiences were carried out in the same conditions as describe in Table 3 but with mitochondria energized with $5 \mathrm{mM}$ succinate in the presence of $3 \mu \mathrm{M}$ rotenone. Data are means \pm S.E.M. of four to five different preparations. Control absolute values are expressed as nanoatoms of oxygen per minute per milligram of protein. Other values are expressed as percent control values.

\begin{tabular}{|c|c|c|c|c|c|}
\hline Berberine & Control & $\begin{array}{c}6.7 \mathrm{nmol} / \mathrm{mg} \\
\text { Protein }\end{array}$ & $\begin{array}{c}16.7 \mathrm{nmol} / \mathrm{mg} \\
\text { Protein }\end{array}$ & $\begin{array}{c}33.4 \mathrm{nmol} / \mathrm{mg} \\
\text { Protein }\end{array}$ & $\begin{array}{c}66.7 \mathrm{nmol} / \mathrm{mg} \\
\text { Protein }\end{array}$ \\
\hline State 3 & $90.7 \pm 10.2$ & $90.8 \pm 5.6$ & $75.8 \pm 1.8^{*}$ & $74.6 \pm 3.6^{*}$ & $58.6 \pm 4.7^{*}$ \\
\hline $\mathrm{RCR}$ & $4.1 \pm 0.4$ & $93.8 \pm 4.1$ & $69.1 \pm 4.4^{*}$ & $62.4 \pm 7.0^{*}$ & $44.9 \pm 4.9^{*}$ \\
\hline $\mathrm{ADP} / \mathrm{O}$ & $1.6 \pm 0.2$ & $91.8 \pm 3.0$ & $94.1 \pm 3.0$ & $83.5 \pm 1.3^{*}$ & $81.4 \pm 3.2^{*}$ \\
\hline Oligomycin & $16.4 \pm 2.1$ & $94.5 \pm 3.5$ & $105.9 \pm 4.7$ & $113.8 \pm 6.2$ & $108.9 \pm 9.4$ \\
\hline FCCP & $152.7 \pm 16.2$ & $85.8 \pm 4.1$ & $79.7 \pm 3.9^{*}$ & $70.6 \pm 7.2^{*}$ & $52.0 \pm 4.4^{*}$ \\
\hline
\end{tabular}

$* p<0.05$ vs. control.

also occurs in isolated mitochondrial fractions, intramitochondrial oxidative stress was measured using the fluorescent probe CM- $\mathrm{H}_{2}$ DCFDA. To pinpoint a possible source of increased oxidative stress in the respiratory chain, we used different substrates and a specific complex I inhibitor (rotenone, $1.5 \mu \mathrm{M}$ ). As demonstrated in Fig. 11, there were no significant differences compared with the control except for the lowest berberine concentration $(6.7 \mathrm{nmol} / \mathrm{mg})$. When using glutamate-malate as substrate and in the absence of rotenone, probe oxidation was higher in the presence of $6.7 \mathrm{nmol}$ berberine/mg protein com- pared with the control. The fluorescence of the probe (due to oxidation) decreased when rotenone was added to the system. No differences were observed when succinate in the presence of rotenone was used, regardless of the berberine concentration used. The observation leads us to assume that reactive oxygen species production can be localized downstream to the rotenone binding site on complex I.

Berberine Does Not Affect ATPase Activity. The differences observed in the ADP/O parameter, along with berberine-induced differences in ADP depolarization and phos- 

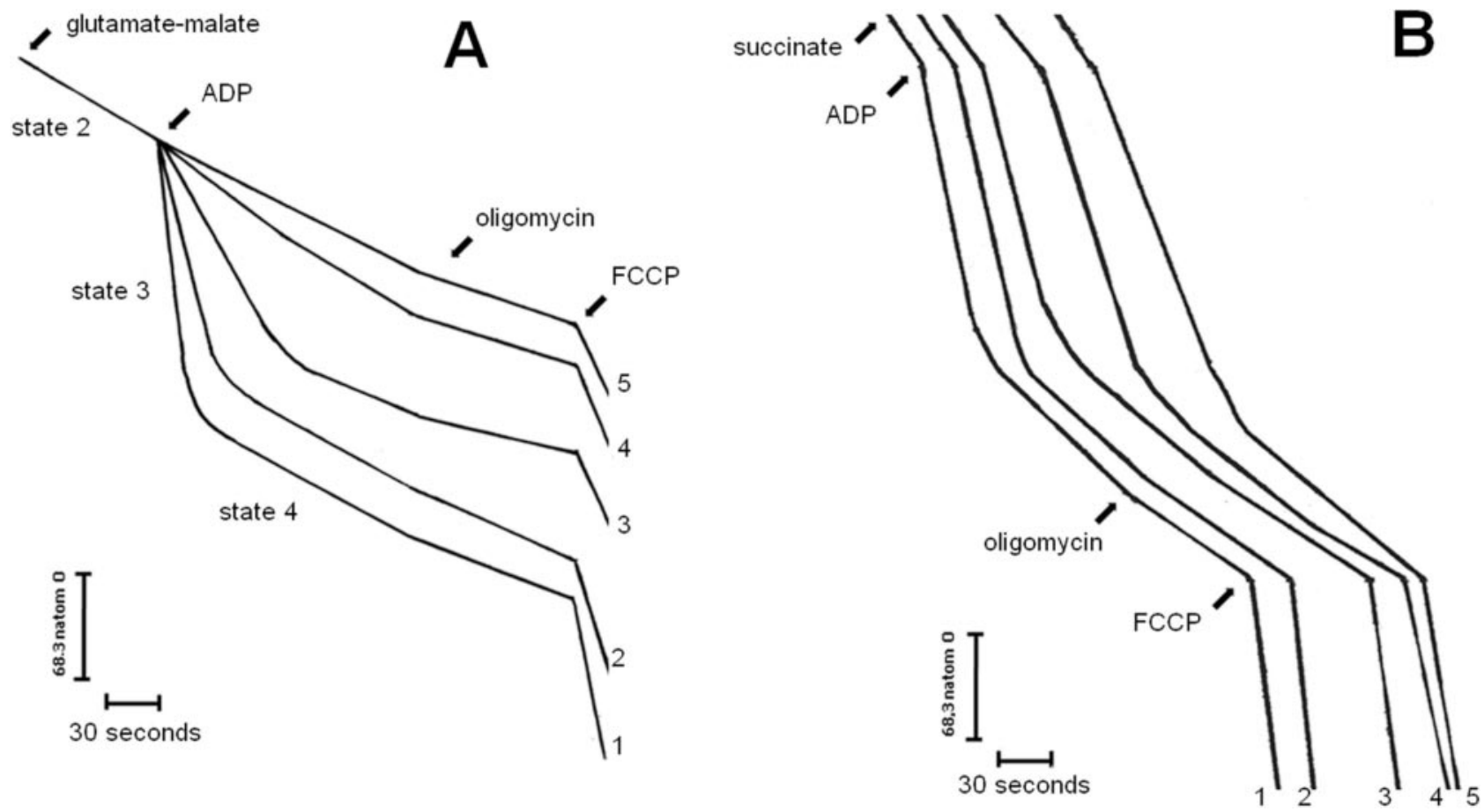

Fig. 7. Typical recording of the effect of berberine on mitochondrial oxygen consumption. Mitochondria (1.5 mg) were incubated in $1 \mathrm{ml}$ of standard reaction media as described under Materials and Methods. Respiration was started by adding $5 \mathrm{mM}$ glutamate plus malate (A) or $5 \mathrm{mM}$ succinate with $3 \mu \mathrm{M}$ rotenone (B). ADP $(125 \mathrm{nmol})$ was added to initiate state 3 . Oligomycin $(1 \mu \mathrm{g})$ and FCCP $(1 \mu \mathrm{M})$ were also added to the system to inhibit passive flux through the ATP synthase and to uncouple respiration, respectively. Berberine, $6.67 \mathrm{nmol} / \mathrm{mg}(2), 16.68$ (3), 33.35 (4), and 66.7 (5), was preincubated during 2 min. Line 1, control situation.

TABLE 5

Effects of berberine on glutamate/malate-energized mitochondria. $\Delta \Psi$ max., ADP depolarization, and lag phase were measured by using a TPP ${ }^{+}$. selective electrode (for further details of the method, see Materials and Methods). The values present are mean \pm S.E.M. n.m., not measurable.

\begin{tabular}{lllc}
\hline & \multicolumn{1}{c}{$\Delta \Psi \max }$. & \multicolumn{1}{c}{ ADP Depolarization } & Lag Phase \\
\hline & & $-m V$ & $s$ \\
Control & $215.2 \pm 5.4(100 \%)$ & $27.5 \pm 1.8(100 \%)$ & $24.0 \pm 2.1(100 \%)$ \\
Berberine & & & $30.5 \pm 4.8(124.1 \pm 9.6 \%)$ \\
$6.7 \mathrm{nmol} / \mathrm{mg}$ protein & $216.5 \pm 2.9(100.9 \pm 2.6 \%)$ & $28.4 \pm 1.5(105.6 \pm 9.4 \%)$ & $35.8 \pm 5.9(144.6 \pm 12.1 \%)$ \\
$16.7 \mathrm{nmol} / \mathrm{mg}$ protein & $217.7 \pm 3.6(101.4 \pm 2.6 \%)$ & $26.5 \pm 1.6 *(98.6 \pm 8.9 \%)$ & $27.1 \pm 8.6 *(171.0 \pm 40.8 \%)$ \\
$33.4 \mathrm{nmol} / \mathrm{mg}$ protein & $215.9 \pm 4.9(100.7 \pm 17.0 \%)$ & $24.5 \pm 1.6 *(76.2 \pm 16.5 \%)$ & n.m. \\
$66.7 \mathrm{nmol} / \mathrm{mg}$ protein & $212.7 \pm 5.2^{*}(99.1 \pm 2.9 \%)$ & $34.6 \pm 5.7(131.6 \pm 21.5 \%)$ & \\
\hline
\end{tabular}

$* p<0.05$ vs. control.

TABLE 6

Effects of berberine on succinate-energized mitochondria

$\Delta \Psi$ max, ADP depolarization, and lag phase were measured by using a $\mathrm{TPP}^{+}$-selective electrode (see Materials and Methods). The values presented represent means \pm S.E.M.

\begin{tabular}{|c|c|c|c|}
\hline & $\Delta \Psi \operatorname{Max}$ & ADP Depolarization & Lag Phase \\
\hline & \multicolumn{2}{|c|}{$-m V$} & $s$ \\
\hline Control & $214.3 \pm 5.8(100 \%)$ & $33.5 \pm 2.5(100 \%)$ & $21.2 \pm 1.4(100 \%)$ \\
\hline \multicolumn{4}{|l|}{ Berberine } \\
\hline $6.7 \mathrm{nmol} / \mathrm{mg}$ protein & $214.0 \pm 3.2(99.8 \pm 2.9 \%)$ & $28.4 \pm 1.0 *(88.0 \pm 9.6 \%)$ & $25.8 \pm 1.9(122.9 \pm 10.2 \%)$ \\
\hline $16.7 \mathrm{nmol} / \mathrm{mg}$ protein & $212.7 \pm 3.5(99.6 \pm 3.0 \%)$ & $24.1 \pm 1.3 *(74.8 \pm 8.9 \%)$ & $29.2 \pm 2.7(139.5 \pm 13.9 \%)$ \\
\hline $33.4 \mathrm{nmol} / \mathrm{mg}$ protein & $209.9 \pm 4.0 *(98.2 \pm 3.1 \%)$ & $17.9 \pm 1.7 *(55.8 \pm 8.2 \%)$ & $37.2 \pm 4.1^{*}(178.1 \pm 21.0 \%)$ \\
\hline $66.7 \mathrm{nmol} / \mathrm{mg}$ protein & $206.2 \pm 4.1 *(96.5 \pm 3.0 \%)$ & $11.3 \pm 2.0 *(35.6 \pm 7.1 \%)$ & $45.6 \pm 3.0^{*}(179.2 \pm 37.1 \%)$ \\
\hline
\end{tabular}

$* p<0.05$ vs. control.

phorylation lag phase as obtained by using a $\mathrm{TPP}^{+}$-selective electrode, suggested that this alkaloid may have a negative effect on mitochondrial ATP synthase (complex V). To test this possibility, ATPase activity experiments were performed. By using two distinct methods, no statistically significant differences were observed between control and berberine-treated mitochondria (Table 8), indicating that berberine apparently does not inhibit complex V activity.

\section{Discussion}

Medicinal herbs have been used for millennia to treat or prevent several maladies such as cancer (Dorai and Aggarwal, 2004). Since most active compounds responsible for the pharmacological effect are still unknown, the literature is rich in research involving purification of the active components and evaluation of their pharmacological use. An impor- 


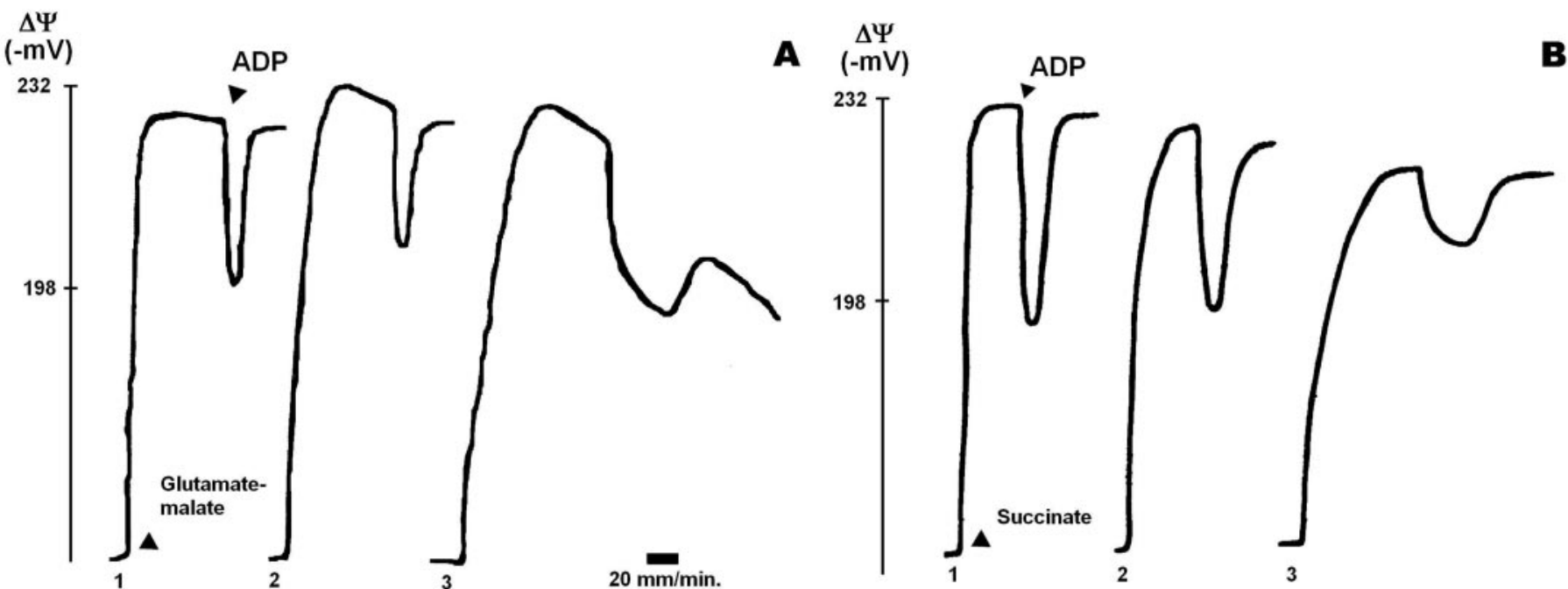

Fig. 8. Representative recording of mitochondrial electric potential measured with a $\mathrm{TPP}^{+}$-selective electrode. Rat liver mitochondria (1.5 mg) were incubated in $1 \mathrm{ml}$ of the medium supplemented with $3 \mu \mathrm{M} \mathrm{TPP}^{+}$. Energization of the mitochondrial population was achieved with $10 \mathrm{mM}$ glutamate-malate (A) or $10 \mathrm{mM}$ succinate plus $3 \mu \mathrm{M}$ rotenone (B). After stabilization of the recording, 125 nmol ADP was added. For more details, see Materials and Methods. Line 2, lowest berberine concentration tested (6.67 nmol/mg protein); line 3, the highest concentration tested (66.7 $\mathrm{nmol} / \mathrm{mg}$ protein). Line 1 , control situation.

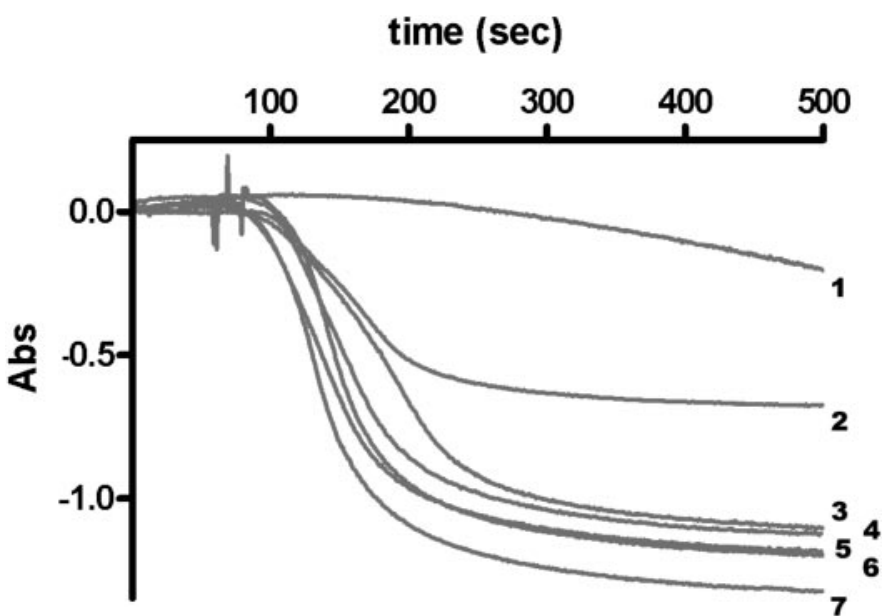

Fig. 9. Typical recording of the effect of berberine on $\mathrm{Ca}^{2+} / \pi$-induced mitochondrial swelling evaluated by the decrease of optical density at 540 $\mathrm{nm}$ caused by calcium. Mitochondria $(1.5 \mathrm{mg})$ were energized by succinate. After a basal line was established, $20 \mu \mathrm{M}$ calcium was added to induce the MPT pore. Berberine was incubated with mitochondria in the following amounts (in nanomoles per milligram of protein): 13.3 (3), 33.3 (4), 66.6 (5), 100.0 (6), and 133.2 (7). Line 2, control situation. Cyclosporin A was preincubated before the addition of calcium and was able to prevent mitochondrial swelling (1). The recordings showed here are representative of at least four different separated mitochondrial preparations.

tant aspect is to investigate the toxic effects of phytochemicals found in traditional medicine on biological systems because many formulations may be found in over-the-counter medications.

In the present work, we demonstrate that berberine inhibits the proliferation of K1375-M2 mouse melanoma cells. Although we did not specifically measure the contributions of cell death and/or cell cycle arrest, it appears that concentrations of berberine up to $100 \mu \mathrm{M}$ do not cause significant levels of death in these cells. By morphological analysis, no typical alterations characteristic of apoptosis or necrosis were found (Serafim et al., 2007). Therefore, the inhibition of proliferation (Fig. 2) results from cell cycle arrest instead of cell death.
TABLE 7

Effects of different berberine concentrations (numbers in the left column) on $\mathrm{Ca}^{2+}$ /phosphate-induced mitochondrial swelling parameters studied by measuring absorbance changes in the suspension in a sucrose-based media

Swelling amplitude was calculated as the difference between basal line absorbance and the absorbance after $500 \mathrm{~s}$. Rate values represent the initial mitochondrial swelling rate after the addition of calcium. Data are means \pm S.E.M. of at least four different experiments.

\begin{tabular}{lcc}
\hline & Amplitude & Swelling Rate \\
\hline & arbitrary units & arbitrary units $/$ min \\
$\mathrm{Ca}^{2+}$ alone & $-0.465 \pm 0.182$ & $-0.045 \pm 0.041$ \\
$\mathrm{Ca}^{2+}+13.3 \mathrm{nmol} /$ & $-1.147 \pm 0.084^{*}$ & $-0.277 \pm 0.041$ \\
$\mathrm{mg}$ protein & & \\
$\mathrm{Ca}^{2+}+33.3 \mathrm{nmol} /$ & $-1.198 \pm 0.059^{*}$ & $-0.505 \pm 0.065^{*}$ \\
$\mathrm{mg}$ protein & $-1.295 \pm 0.050^{*}$ & $-0.472 \pm 0.100^{*}$ \\
$\mathrm{Ca}^{2+}+66.6 \mathrm{nmol} /$ & $-1.045 \pm 0.237^{*}$ & $-0.367 \pm 0.142^{*}$ \\
$\mathrm{mg}$ protein & $-1.281 \pm 0.119^{*}$ & $-0.346 \pm 0.035$ \\
$\mathrm{Ca}^{2+}+100 \mathrm{nmol} /$ & & \\
$\mathrm{mg}$ protein & & $-0.047 \pm 0.036 \dagger$ \\
$\mathrm{Ca}^{2+}+133.2 \mathrm{nmol} /$ & & \\
$\mathrm{mg}$ protein & & \\
$\mathrm{Ca}^{2+}+133.2 \mathrm{nmol} /$ & $-0.241 \pm 0.159 \dagger$ & \\
$\mathrm{mg}$ protein $+\mathrm{CsA}$ & &
\end{tabular}

$* p<0.05$ vs. control.

$\dagger p<0.05$ vs. $\mathrm{Ca}^{2+}+133.2 \mathrm{nmol}$ berberine/mg protein.

Our data contrast with works from other laboratories (Kuo et al., 1995; Hwang et al., 2006; Letasiova et al., 2006; Lin et al., 2006; Mantena et al., 2006b), where berberine was found to promote apoptosis. However, many of these studies used concentrations of berberine much higher than those used here. In addition, different cell lines have been show to exhibit significantly different sensitivities to apoptotic induction by berberine (Letasiova et al., 2006).

The advantages of the fluorescence properties of berberine were used to demonstrate that the drug primarily accumulates in mitochondria. These results are in agreement with previous studies (Serafim et al., 2007) where we demonstrated that berberine is accumulated primarily in mitochondria at lower concentrations (up to approximately $50 \mu \mathrm{M}$ ) but becomes detectable in the nucleus and cytoplasm at higher concentrations (over $50 \mu \mathrm{M}$ ), possibly due to saturation of the 


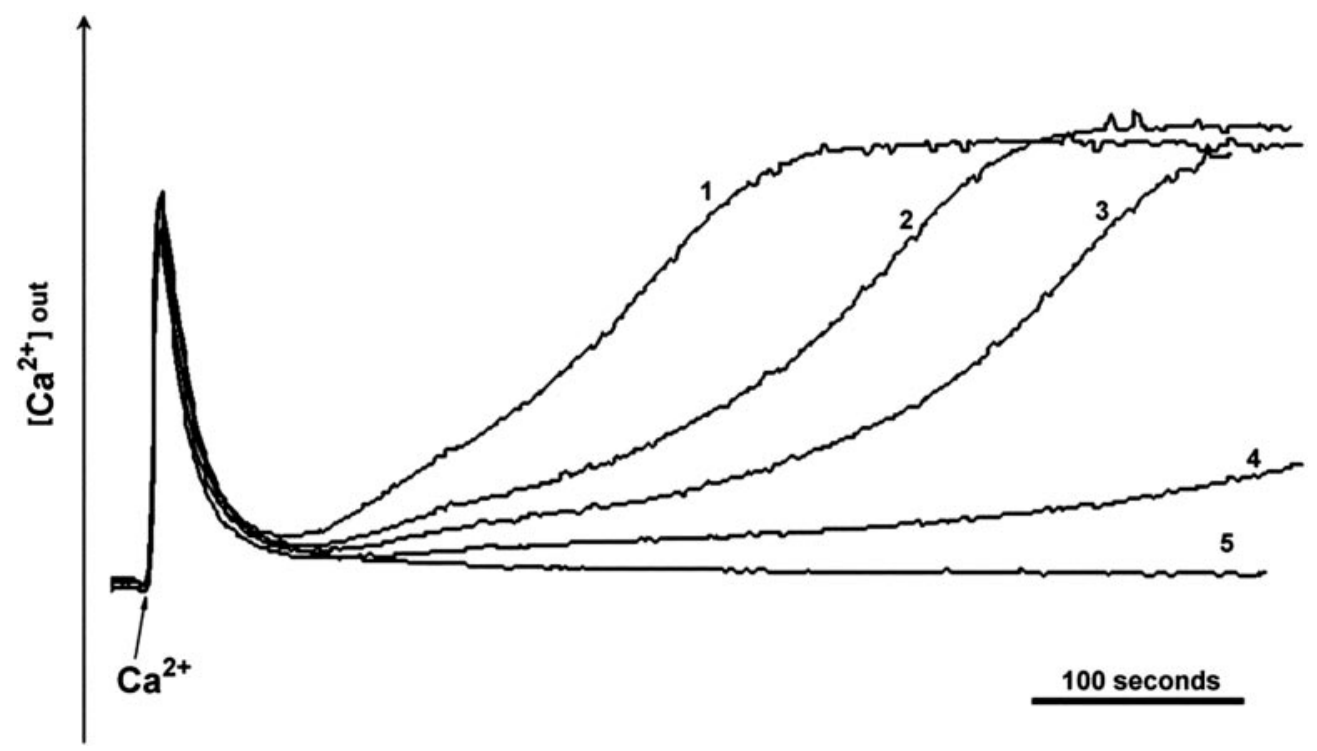

Fig. 10. Assessment of mitochondrial calcium loading capacity in the presence of berberine. Berberine was incubated with mitochondria $(0.4 \mathrm{mg})$ in the following amounts: $1,31.2 \mathrm{nmol} /$ $\mathrm{mg} ; 2,15.6 \mathrm{nmol} / \mathrm{mg} ; 3,6.2 \mathrm{nmol} / \mathrm{mg}$; and $5,31.2 \mathrm{nmol} / \mathrm{mg}$ berberine in the presence of cyclosporin A $(100 \mathrm{nM})$. Line 4, control situation. The fluorescent probe Calcium Green 5-N (100 $\mathrm{nM}$ ) was used to evaluate the levels of extramitochondrial calcium as described under Materials and Methods.

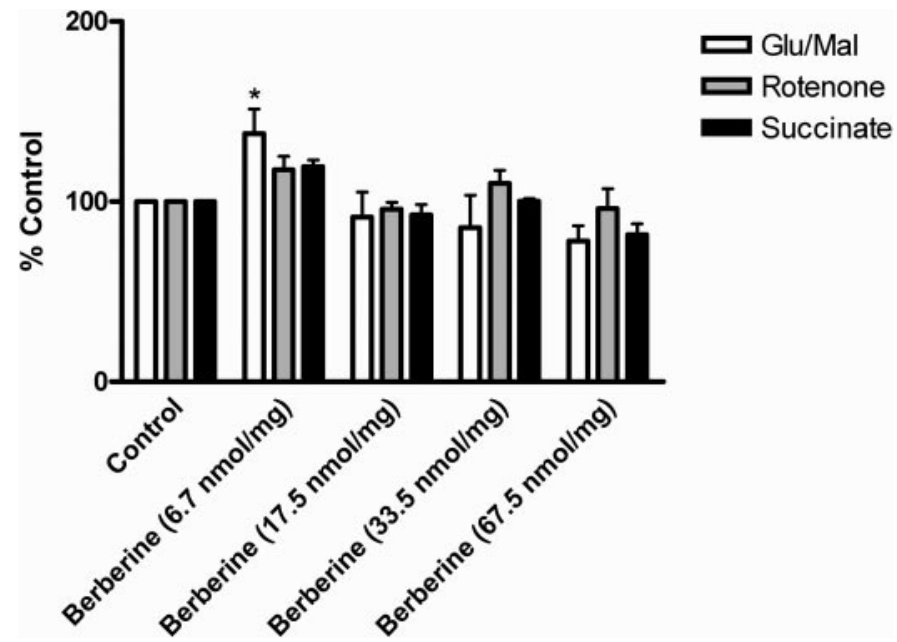

Fig. 11. Evaluation of intramitochondrial reactive oxygen species production by using the fluorescent probe $\mathrm{CM}-\mathrm{H}_{2} \mathrm{DCFDA}$. Mitochondria ( 1 $\mathrm{mg}$ ) were incubated in $2 \mathrm{ml}$ of the standard reaction media $(250 \mathrm{mM}$ sucrose and $10 \mathrm{mM}$ HEPES-KOH, $\mathrm{pH}$ 7.4) as described under Materials and Methods. After predetermined time intervals, rotenone $(1.5 \mu \mathrm{M})$ and succinate $(2.5 \mathrm{mM})$ were added to the system. The graphic shows the variation of fluorescence rate relative to the control condition. White bars, glutamate/malate; gray bars, glutamate/malate in the presence of rotenone; black bars, succinate. $*, p<0.05$ versus respective control.

\section{TABLE 8}

Measurement of ATPase activity using two distinct methods: in the first column, the detection of $\mathrm{pH}$ changes associated with ATP hydrolysis was measured with a $\mathrm{pH}$ electrode (see Materials and Methods); in the second method tested, $\Delta \psi$ generated by ATP hydrolysis was measured by using a TPP-selective electrode Values are means \pm S.E.M. of three different mitochondrial preparations.

\begin{tabular}{lcc}
\hline & $\begin{array}{c}\mathrm{nmol} \mathrm{H}^{+} / \\
\mathrm{mg} \text { Protein }\end{array}$ & $\Delta \Psi(-\mathrm{mV})$ \\
\hline Control & $3.6 \pm 0.2$ & $166.8 \pm 2.0$ \\
$33.4 \mathrm{nmol}$ Berberine/mg protein & $3.9 \pm 0.2$ & $166.6 \pm 1.6$ \\
$66.7 \mathrm{nmol}$ Berberine/mg protein & $4.1 \pm 0.4$ & $167.7 \pm 1.4$ \\
\hline
\end{tabular}

$* p<0.05$ vs. control.

mitochondrial compartment. Berberine is a positively charged isoquinolinium molecule; such compounds are more active inhibitors of the mitochondrial respiratory chain than uncharged molecules when tested on isolated mitochondria
(Barreto et al., 2003), which may reflect a stronger affinity for the negatively charged matrix. Likewise, we demonstrate that the mitochondrial electric transmembrane potential is a driving force for drug accumulation because FCCP prevents mitochondrial berberine fluorescence. Mikes and Dadak (1983) presented similar results, although an increase in berberine fluorescence quantum yield upon mitochondrial energization was suggested as the explanation (Mikes and Dadak, 1983). One crucial piece of data from our results is the appearance of berberine fluorescence in nuclei or cytoplasm after incubation of cells with FCCP and berberine concentrations that do not normally stain nuclei and cytoplasm. One would expect that if mitochondrial-localized berberine was mostly losing its fluorescence quantum yield upon FCCP treatment, then nuclei and cytoplasm should not change their fluorescence characteristics. The primary accumulation in mitochondria versus other cell compartments can also help explain the effect of the compound in promoting cell cycle arrest versus cell death. In fact, certain other positively charged isoquinolines are primarily accumulated in the nucleus and act through promoting cell death (e.g., sanguinarine; J. Matos and P. J. Oliveira, unpublished data) with few alterations in mitochondrial bioenergetics (Barreto et al., 2003).

Mitochondria are well known to produce free radicals as a consequence of mitochondrial respiration (Sastre et al., 2000). Assays with dichlorofluorescein, a probe whose fluorescence increase in the presence of oxidants, show that berberine increases oxidative stress in K1735-M2 cells. To clarify whether increased oxidative stress results from mitochondrial interactions, experiments on isolated mitochondria were conducted. Results show that berberine, for the lowest concentration tested, increases oxidative stress on isolated liver mitochondria when using complex I substrates, which may help explain results in intact cells exposed to berberine. Increased oxidative stress can be attributed to an interaction of berberine at a site downstream of the rotenone binding site because this inhibitor inhibits berberine-induced oxidative stress. Even without using alternative inhibitors of the respiratory chain, it is likely that the site is located on complex I because berberine does not produce significant oxidative 
stress in rotenone-treated mitochondria energized with succinate. These actions resemble those of doxorubicin, an anthracycline used in anticancer therapy that generates oxidative stress at mitochondrial complex I (Berthiaume and Wallace, 2007). As described, increased oxidative stress occurs only for the lowest berberine concentrations, which can be explained by a report demonstrating that berberine possesses antioxidant properties (Hwang et al., 2002). It is possible that at lower concentrations, pro-oxidant actions through inhibition of Complex I outweigh the antioxidant activity of berberine, whereas at higher concentrations, the antioxidant activity prevails over the pro-oxidant effects.

It is reasonable to think that berberine, once accumulated within the mitochondria, affects oxidative phosphorylation efficiency and compromises the normal behavior of the cell. The decrease in cell ATP concentration observed after berberine treatment can explain the cell cycle arrest because ATP has been described to regulate the cell cycle (Gemin et al., 2005).

When comparing standard respiratory parameters in isolated rat liver mitochondria, berberine inhibition of oxygen consumption is more pronounced when respiratory substrates for complex I are used. Barreto et al. (2003) have also demonstrated that berberine affects more the activity of the isolated NADH dehydrogenase (complex I) compared with the isolated succinate dehydrogenase (complex II). Mikes et al. (Mikes and Dadak, 1983; Mikes and Yaguzhinskij, 1985) also observed that berberine derivatives have a predominant effect on mitochondrial complex I. The results from the present study indicate that although berberine appears to have a predominant effect when complex I substrates are used, succinate-sustained respiration is also inhibited, suggesting a broader range of targets in the respiratory chain.

The analysis of $\mathrm{ADP} / \mathrm{O}, \mathrm{ADP}$ depolarization, and lag phase also suggest that berberine interacts with the mitochondrial phosphorylative system. One of the constituents of the phosphorylative system is the ATP synthase, which is responsible for the production of ATP. Two distinct experiments show that berberine does not affect complex V activity. However, there are other constituents of the phosphorylative system such as the adenine nucleotide transporter or the phosphate uniporter that can also be possible targets for berberine action. In fact, one attractive candidate is the adenine nucleotide translocator because it is also a component of the MPT pore (see below). Work is currently underway to clarify this question. The effects of berberine on isolated mitochondria can explain the decrease in energy status observed in intact cells treated with this alkaloid.

The presence of berberine in mitochondria seems to increase the susceptibility to MPT pore opening since swelling amplitude is increased when berberine is added. Results obtained using a fluorescent calcium probe confirmed the swelling results, indicating that berberine decreases mitochondrial calcium loading capacity through increased induction of the MPT pore. Interestingly, electron microscopy shows that most mitochondria from berberine-treated cells are swollen, pale, and lack identifiable cristae, suggesting that they have undergone the MPT. MPT pore opening in intact cells is still a controversial topic because several cytosolic factors may alter MPT pore gating properties. However, the occurrence of the MPT pore induced by berberine is a possible explanation to the decreased number of mitochondrial bodies and swollen aspect of most mitochondria.

Although normal liver and cancer cell mitochondria may present certain structural and functional differences, we believe that sufficient similarities exist to justify using isolated liver mitochondria as models to gain insights into the actions of xenobiotic compounds with the mitochondrial system of malignant cells. In addition, isolated fractions present the advantage of a much higher isolation yield so that more aspects of mitochondrial function can be studied with one single isolation procedure.

Two observations from this work deserve future attention. First, we have observed that berberine enhances the calciuminduced permeability transition in isolated liver mitochondrial fractions, at least from morphological data, apparently as well in intact cells. We tried to use cyclosporin A to test the possibility that berberine also stimulates the MPT in intact cells, but berberine effects were actually exacerbated (data not shown), which can be attributed to inhibition of berberine efflux by cyclosporin A (Sonneveld and Wiemer, 1997). It is interesting that the enhanced MPT occurrence in intact cells, if confirmed, did not result in K1735-M2 cell death, although it is reasonable to speculate that the decrease in mitochondrial mass may be related to mitochondrial destruction induced by the MPT. The second interesting observation deals with the decrease of mtDNA copy number for 25 but not for $100 \mu \mathrm{M}$. Berberine is known to intercalate into doublestranded DNA, forming adducts that can inhibit DNA replication (Kuo et al., 1995), which could explain the reduced mtDNA copy numbers in cells treated with low concentrations of berberine. It is possible that the lack of reduction in mtDNA copy number in cells treated with $100 \mu \mathrm{M}$ berberine reflects a compensatory mechanism that attempts to overcome the decreased mitochondrial ATP production by increased mtDNA copy number. Alternatively, it could be that the higher levels of oxidative stress induced by lower concentrations of berberine result in mtDNA destruction that is either blocked by the antioxidant effects of higher concentrations of berberine or somehow inhibited by a "protective" effect of a larger quantity of intercalated berberine. It would be of interest to obtain and compare accurate measures of mitochondrial mass with mtDNA quantity in cells treated with different concentrations of berberine.

During several cell events (including apoptosis), mitochondrial fragmentation is observed, which results in smaller, rounder, and more numerous mitochondria (Arnoult, 2007). The results from epifluorescence microscopy show that the mitochondrial network is dissipated after berberine treatment, but the number of mitochondria does not increase as shown by EM. A possible explanation is that the fragmented mitochondria are damaged and end up being destroyed. The results demonstrate that the mitochondrial network is strongly affected by berberine, but the cause is not immediately clear. It has been demonstrated that oxidative stress causes mitochondrial fragmentation (Sardão et al., 2007), and the increased oxidative stress observed after treatment with low doses of berberine could explain the vesiculation of the mitochondrial network observed by epifluorescence microscopy. Unfortunately, the extensive mitochondrial depolarization induced by high concentrations of berberine makes observation of mitochondrial morphology with charge-dependent probes like TMRM difficult. 
The present work shows that berberine is accumulated by mitochondria of a mouse melanoma cell line, leading to mitochondrial fragmentation and dysfunction, accompanied by decreased cellular energy charge. When the effect was compared with the results obtained on isolated mitochondrial fractions, it is observed that regardless of the system used, berberine is toxic for mitochondria. One major limitation of the present study (as in many others) is the lack of knowledge of the real concentration of berberine that reaches mitochondria in intact cells. Although we do not possess data regarding this aspect, it is wise to speculate that mitochondrial berberine concentrations will be much higher than in the bulk cytosol due to electrophoretic accumulation. We believe that the range of berberine concentrations accumulated by mitochondria in intact cells is within the range of concentrations used on isolated mitochondrial fractions in the present study. The present work not only provides insights on the mechanism by which berberine interferes with tumor cell proliferation, demonstrating previously unknown effects on mitochondrial physiology, but also raises a note of caution on the use of berberine as a nontoxic "natural" over-the-counter medication.

\section{References}

Arnoult D (2007) Mitochondrial fragmentation in apoptosis. Trends Cell Biol 17:612 .

Asai M, Iwata N, Yoshikawa A, Aizaki Y, Ishiura S, Saido TC, and Maruyama K (2007) Berberine alters the processing of Alzheimer's amyloid precursor protein to decrease A beta secretion. Biochem Biophys Res Commun 352:498-502.

Barreto MC, Pinto RE, Arrabaca JD, and Pavao ML (2003) Inhibition of mouse liver respiration by Chelidonium majus isoquinoline alkaloids. Toxicol Lett 146:37-47. Bernardi P, Krauskopf A, Basso E, Petronilli V, Blalchy-Dyson E, Di Lisa F, and Forte MA (2006) The mitochondrial permeability transition from in vitro artifact to disease target. FEBS $J$ 273:2077-2099.

Berthiaume JM and Wallace KB (2007) Adriamycin-induced oxidative mitochondrial cardiotoxicity. Cell Biol Toxicol 23:15-25.

Bouchier-Hayes L, Lartigue L, and Newmeyer DD (2005) Mitochondria: pharmacological manipulation of cell death. J Clin Invest 115:2640-2647.

Broekemeier KM, Dempsey ME, and Pfeiffer DR (1989) Cyclosporine a is a potent inhibitor of the inner membrane-permeability transition in liver mitochondria. $J$ Biol Chem 264:7826-7830.

Carvalho AP, Vale MG, and Madeira VM (1974) Regulation of ATPase of sarcoplasmic-reticulum (Sr) studied in presence of antibiotic X-537a. Fed Proc 33:1332

Dorai T and Aggarwal BB (2004) Role of chemopreventive agents in cancer therapy. Cancer Lett 215:129-140.

Fukuda K, Hibiya Y, Mutoh M, Koshiji M, Akao S, and Fujiwara H (1999) Inhibition by berberine of cyclooxygenase-2 transcriptional activity in human colon cancer cells. J Ethnopharmacol 66:227-233.

Gemin A, Sweet S, Preston TJ, and Singh G (2005) Regulation of the cell cycle in response to inhibition of mitochondrial generated energy. Biochem Biophys Res Communs 332:1122-1132.

Gornall AG, Bardawill CJ, and David MM (1949) Determination of serum proteins by means of the biuret reaction. $J$ Biol Chem 177:751-766.

Helige C, Smolle J, Zellnig G, Finkpuches R, Kerl H, and Tritthart HA (1993) Effect of desqualinium on K1735-M2 melanoma cell growth, directional migration and invasion in vitro. Eur $J$ Cancer 29A:124-128.

Hwang JM, Kuo HC, Tseng TH, Liu JY, and Chu CY (2006) Berberine induces apoptosis through a mitochondria/caspases pathway in human hepatoma cells. Arch Toxicol 80:62-73.

Hwang JM, Wang CJ, Chou FP, Tseng TH, Hsieh YS, Lin WL, and Chu CY (2002) Inhibitory effect of berberine on tert-butyl hydroperoxide-induced oxidative damage in rat liver. Arch Toxicol 76:664-670.

Jantova S, Cipak L, and Letasiova S (2007) Berberine induces apoptosis through a mitochondrial/caspase pathway in human promonocytic U937 cells. Toxicol in Vitro 21:25-31.

Kamo N, Kobatake Y, Muratsugu M, and Hongoh R (1979) Membrane potential of mitochondria measured with an electrode sensitive to tetraphenyl phosphonium and relationship between proton electrochemical potential and phosphorylation potential in steady state. J Membr Biol 49:105-121.

Kirveliene V, Sadauskaite A, Kadziauskas J, Sasnauskiene S, and Juodka B (2003) Correlation of death modes of photosensitized cells with intracellular ATP concentration. FEBS Lett 553:167-172.

Ko WH, Yao XQ, Lau CW, Law WI, Chen ZY, Kwok W, Ho K, and Huang Y (2000) Vasorelaxant and antiproliferative effects of berberine. Eur J Pharmacol 399:187196

Kuo CL, Chi CW, and Liu TY (2004) The anti-inflammatory potential of berberine in vitro and in vivo. Cancer Lett 203:127-137.

Kuo CL, Chou CC, and Yung BYM (1995) Berberine Complexes with DNA in the Berberine-Induced Apoptosis in Human Leukemic Hl-60 Cells. Cancer Lett 93: $193-200$.

Lee HJ, Son DH, Lee SK, Lee J, Jun CD, Jeon BH, Lee SK, and Kim EC (2006) Extract of Coptidis rhizoma induces cytochrome-c dependent apoptosis in immortalized and malignant human oral keratinocytes. Phytol Res 20:773-779.

Letasiova S, Jantova S, Cipak L, and Muckova M (2006) Berberine: antiproliferative activity in vitro and induction of apoptosis/necrosis of the U937 and B16 cells. Cancer Lett 239:254-262.

Lin HL, Liu TY, Wu CW, and Chi CW (1999) Berberine modulates expression of mdr1 gene product and the responses of digestive track cancer cells to Paclitaxel. Br J Cancer 81:416.

Lin JP, Yang JS, Lee JH, Hsieh WT, and Chung JG (2006) Berberine induces cell cycle arrest and apoptosis in human gastric carcinoma SNU-5 cell line. World $J$ Gastroenterol 12:21-28.

Lin SK, Tsai SC, Lee CC, Wang BW, Liou JY, and Shyu KG (2004) Berberine inhibits HIF-1 alpha expression via enhanced proteolysis. Mol Pharm 66:612-619.

Mantena SK, Sharma SD, and Katiyar SK (2006a) Berberine inhibits growth, induces G(1) arrest and apoptosis in human epidermoid carcinoma A431 cells by regulating Cdki-Cdk-cyclin cascade, disruption of mitochondrial membrane potential and cleavage of caspase 3 and PARP. Carcinogenesis 27:2018-2027.

Mantena SK, Sharma SD, and Katiyar SK (2006b) Berberine, a natural product, induces G(1)-phase cell cycle arrest and caspase-3-dependent apoptosis in human prostate carcinoma cells. Mol Cancer Ther 5:296-308.

Mikes V and Dadak V (1983) Berberine derivatives as cationic fluorescent probes for the investigation of the energized state of mitochondria. Biochim Biophys Acta 723:231-239

Mikes V and Yaguzhinskij LS (1985) Interaction of fluorescent berberine alkyl derivatives with respiratory chain of rat liver mitochondria. J Bioenerg Biomembr 17:23-32.

Papazisis KT, Geromichalos GD, Dimitriadis KA, and Kortsaris AH (1997) Optimization of the sulforhodamine B colorimetric assay. J Immunol Meth 208:151-158

Rabbani GH, Butler T, Knight J, Sanyal SC, and Alam K (1987) Randomized controlled trial of berberine sulfate therapy for diarrhea due to enterotoxigenic Escherichia coli and Vibrio cholerae. J Infect Dis 155:979-984.

Rajdev S and Reynolds IJ (1993) Calcium Green-5N, a novel fluorescent probe for monitoring high intracellular free $\mathrm{Ca}^{2+}$ concentrations associated with glutamate excitotoxicity in cultured rat brain neurons. Neurosci Lett 162:149-152.

Sardão VA, Oliveira PJ, Holy J, Oliveira CR, and Wallace KB (2007) Vital imaging of H9c2 myoblasts exposed to tert-butylhydroperoxide: characterization of morphological features of cell death. BMC Cell Biol 8:11.

Sastre J, Pallardo FV, and Vina J (2000) Mitochondrial oxidative stress plays a key role in aging and apoptosis. IUBMB Life 49:427-435.

Serafim TL, Oliveira PJ, Sardao VA, Perkins E, Parke D, and Holy J (2007) Different concentrations of berberine result in distinct cellular localization patterns and cell cycle effects in a melanoma cell line. Cancer Chemother Pharmacol, in press.

Shirwaikar A, Shirwaikar A, Rajendran K, and Punitha ISR (2006) In vitro antioxidant studies on the benzyl tetra isoquinoline alkaloid berberine. Biol Pharm Bull 29:1906-1910.

Sonneveld P and Wiemer E (1997) Inhibitors of multidrug resistance. Curr Opin Oncol 9:543-548.

Stermitz FR, Lorenz P, Tawara JN, Zenewicz LA, and Lewis K (2000) Synergy in a medicinal plant: Antimicrobial action of berberine potentiated by 5 '-methoxyhydnocarpin, a multidrug pump inhibitor. Proc Natl Acad Sci U S A 97:1433-1437.

Thundathil J, Filion F, and Smith LC (2005) Molecular control of mitochondrial function in preimplantation mouse embryos. Mol Reprod Dev 71:405-413.

Address correspondence to: Dr. Paulo J. Oliveira, Center for Neurosciences and Cell Biology, Department of Zoology, University of Coimbra, P-3004-517 Coimbra, Portugal. E-mail: pauloliv@ci.uc.pt 